\title{
Study on the Extravital Culture of the Marrow and the Spleen of the Rabbits suffered from Alloxan-diabetes and the Effects on the Extravital Culture of the Marrow and the Spleen of the Normal Rabbits by Addition of the Serum of the Rabbits suffered from Alloxan-diabetes
} By

\section{MASUdA, M. OKUMURA}

Department of Medicine, Kyoto Pref. Med. University. (Director: Prof. S. Tateishi. M.D.)

\begin{abstract}
We observed the extravital culture of the marrow and the spleen of the rabbits suffered from alloxan diabetes and the effects on the extravital culture of the marrow and the spleen of the normal rabbits by the addition of the glucose solution and the serum of the rabbits suffered from alloxan diabetes.
\end{abstract}

1) The growth of the marrow and the spleen of the rabbits suffered from alloxan diabetes is poorer than the normals.

2) The extravital culture of the marrow and spleen is controled by the addition of the serum of the rabbits suffered from alloxan diabetes.

3) When the serum of the rabbits suffered from alloxan diabetes is inactivited by the heat; filtered by the chamberland filter L: and absorbed by the absorbents (Caorin and blood coal powder,) its controllable power is reduced.

4) But, the dealed serum with these methods has the stronger controllable power than the non-deald normals.

5) The dealed normal serum has the almost same controllable power as the non-dealed norma! serum.

6) There is no intimate relationship between the control and the glucose concentrations. 


\title{
体外培養アロキサン糖㲾家鬼骨随, 脾臓組織の 生育に関する政究並びに組織の生育に及ぼす アロキサン糖尿家鬼血清の影響
}

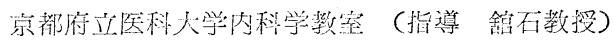 \\ 研究科学生 增 田 一 郎 \\ 研究科学生 奥 村 迠 -
}

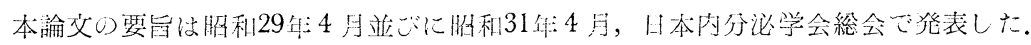

\begin{tabular}{|c|c|c|}
\hline 目 & 次 & \\
\hline 第 1 章 緒 & \multicolumn{2}{|r|}{ の組織生育に及ぼす影響 } \\
\hline 第 2 章 実験材料业じに奏䮖乃法 & \multirow[t]{2}{*}{ 第 3 飾 } & 行「ア」糖尿家鬼処置血清の組織生育 \\
\hline 第 1 節 垁験動物並びに臟唯紐織 & & に及はす寸影響 \\
\hline 第 2 節 実験方法 & \multirow[t]{2}{*}{ 第 4 節 } & 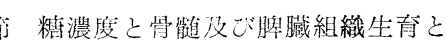 \\
\hline 第 3 章 実験成縝 & & の関係 \\
\hline 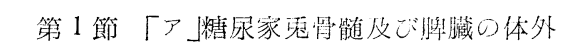 & \multicolumn{2}{|c|}{ 第 4 章 総括並びに洘按 } \\
\hline 培巍生育過程について & \multirow[t]{2}{*}{ 第 5 章 } & 結論 \\
\hline 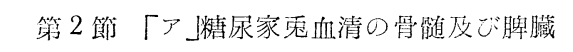 & & 交㬏 \\
\hline 第1章 緒 & & 言 \\
\hline
\end{tabular}

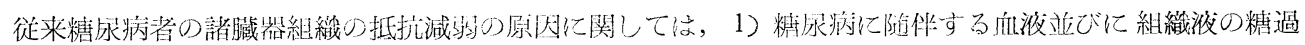

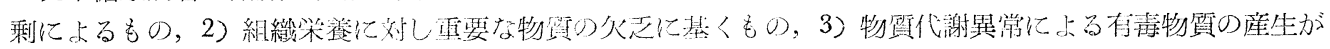

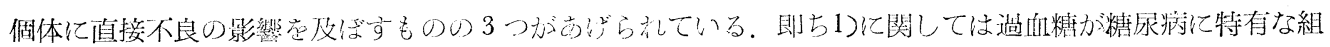

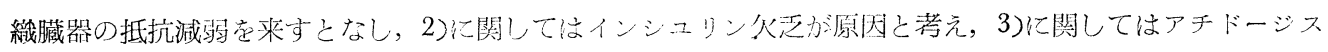

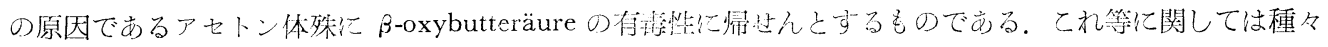

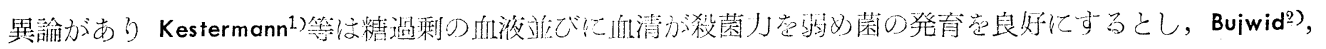

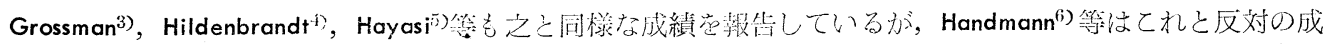

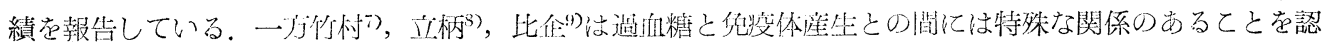

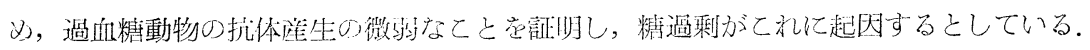

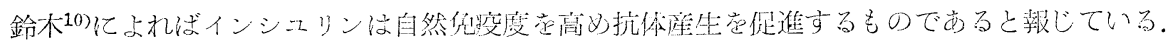

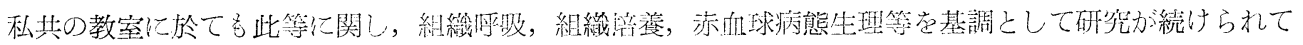

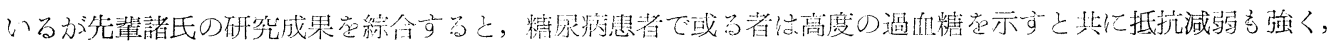

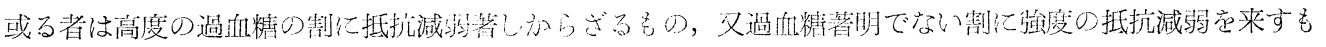

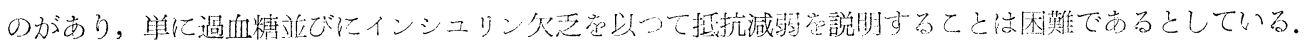

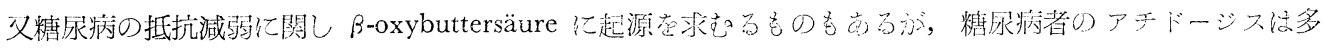

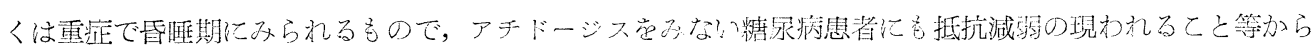
しててれ莨以つて原因とするは理解し難いるのと考光られている。

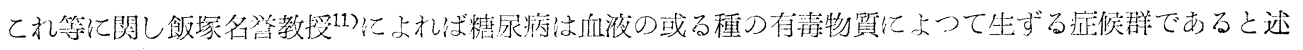
符32巻 符 8 号 


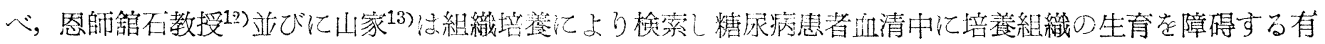

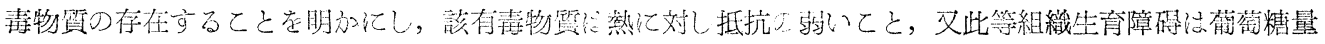

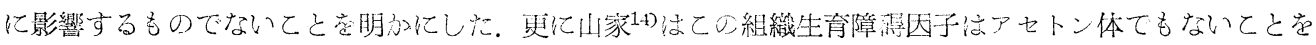
証明したのである。

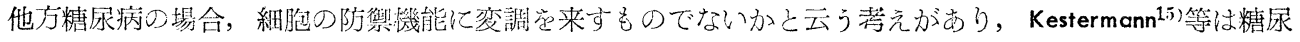

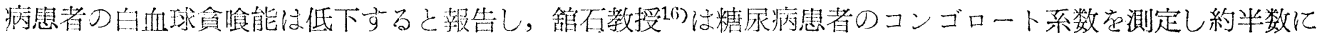
細網内皮系の機能の減退するの学みたと報告している等，楉尿病の場合細絽内皮系の機能の減退が考元られ る.

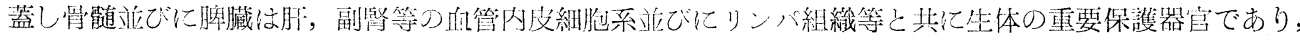

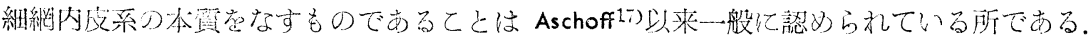

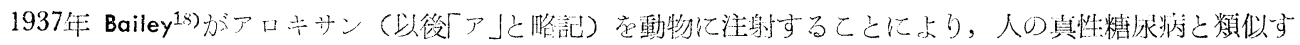

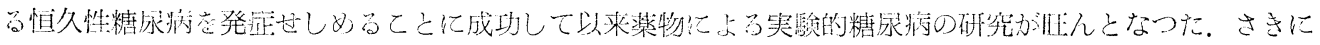

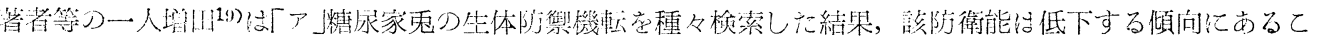

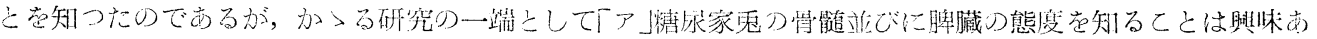

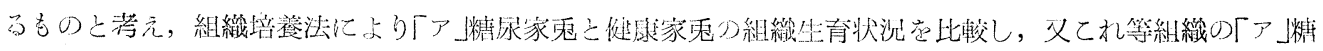

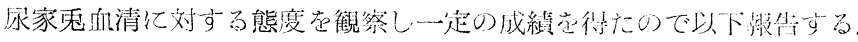

\section{第2章＼cjkstart実験材料並びに実験方法}

\section{第 1 節 実験動物並びに実験方法}

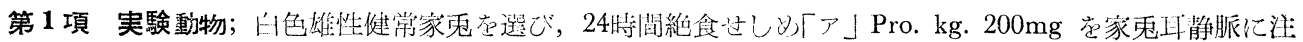

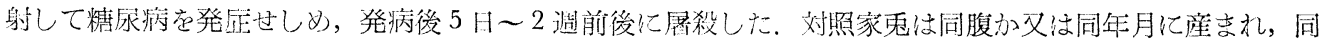
一采件见飼育したもの造えだ。

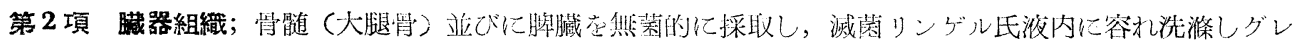
フ・氏刀で約 $1 \mathrm{nmm}$ 平方の切㸝とする。

\section{第 2 節 実 験 方 法}

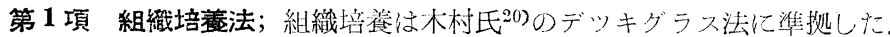

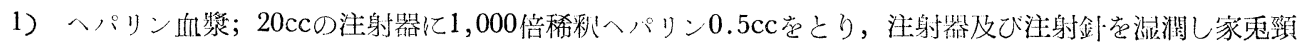
動脈上り想菌的に採取した。

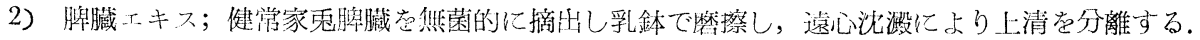

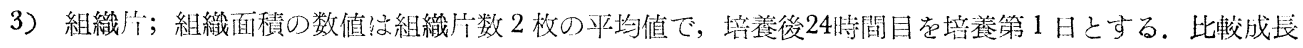

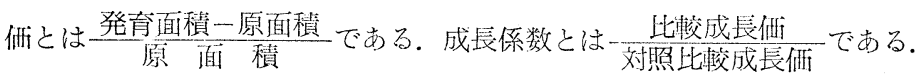

第 2 項 血糖量測定；Hagedorn-Jensen 尤法による。

\section{第3章 実 験 成 績}

\section{第 1 節「ア糖尿家兔骨䯣及び脾臟の体外培盉生育過程について}

第 1 項骨㓩遀

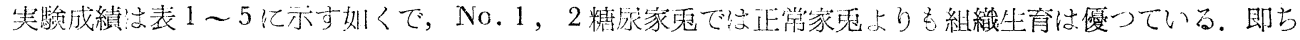

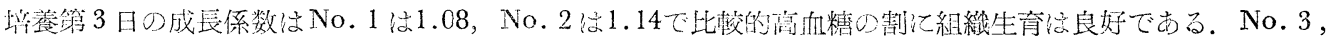

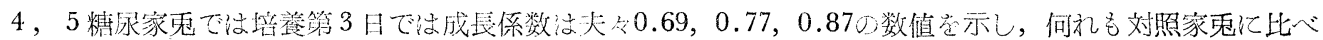

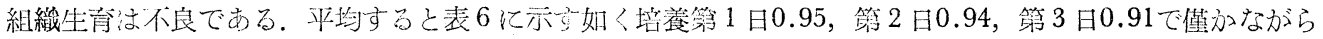
刘照上り劣る傾向にある，以上を一括して平均值の上から成長係数を求めてみると，概して骨髄の生育は対 
管 1 表 藏㟧組織生育 (骨㖪)

\begin{tabular}{|c|c|c|c|c|c|c|c|c|c|c|c|c|c|c|c|}
\hline \multirow{3}{*}{ 家兔番昭 } & \multirow{3}{*}{$\begin{array}{l}\text { 血糖星 } \\
\mathrm{mg} / \mathrm{dl} \\
\left(\begin{array}{l}\text { 生存 } \\
\text { 日数 }\end{array}\right)\end{array}$} & \multirow{3}{*}{$\begin{array}{l}\text { 原 } \\
\text { 面 } \\
\text { 積 }\end{array}$} & \multirow{3}{*}{ 平 } & \multicolumn{4}{|c|}{ 培 } & \multicolumn{4}{|c|}{ 獣 } & \multicolumn{4}{|c|}{ 数 } \\
\hline & & & & \multicolumn{2}{|c|}{ 筑 } & 1 & & \multicolumn{2}{|c|}{ 第 } & 2 & & \multicolumn{2}{|c|}{ 第 } & 3 & 日 \\
\hline & & & & $\begin{array}{l}\text { 発育 } \\
\text { 面稳 }\end{array}$ & 计均 & 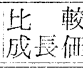 & 成辰 & $\begin{array}{l}\text { 㥕育 } \\
\text { 画棈 }\end{array}$ & 㴆均 & {$\left[\begin{array}{l}\text { 比軦 } \\
\text { 成苓佃 }\end{array}\right.$} & $\begin{array}{l}\text { 成係 } \\
\text { 数 }\end{array}$ & $\begin{array}{l}\text { 発育 } \\
\text { 南䅡 }\end{array}$ & 平均 & 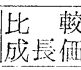 & 成㷳 \\
\hline No. 1 & $\begin{array}{r}400 \\
(10)\end{array}$ & $\begin{array}{l}1.6 \\
1.6 \\
1.5 \\
1.5 \\
1.5 \\
1.5 \\
1.5\end{array}$ & 1.5 & $\begin{array}{l}32.3 \\
31.7 \\
31.5 \\
30.8 \\
30.2 \\
29.2 \\
29.6\end{array}$ & 31.0 & 19.7 & 1.14 & $\begin{array}{l}34.8 \\
34.4 \\
33.9 \\
33.5 \\
33.3 \\
32.7 \\
32.2\end{array}$ & 33.5 & 21.3 & 1.08 & $\begin{array}{l}37.2 \\
36.8 \\
36.4 \\
35.8 \\
35.5 \\
34.4 \\
34.1\end{array}$ & 35.7 & 22.8 & 1.08 \\
\hline 刘 煦 & 112 & \begin{tabular}{l|}
1.6 \\
1.6 \\
1.5 \\
1.5 \\
1.5 \\
1.4 \\
1.4
\end{tabular} & 1.5 & $\begin{array}{l}29.2 \\
28.7 \\
28.5 \\
27.9 \\
27.8 \\
27.2 \\
26.9\end{array}$ & 28.0 & 17.3 & & $\begin{array}{l}32.3 \\
31.8 \\
31.3 \\
30.8 \\
30.5 \\
30.3 \\
29.7\end{array}$ & 31.0 & 19.7 & & $\begin{array}{l}34.9 \\
34.4 \\
33.8 \\
33.4 \\
32.7 \\
32.2 \\
31.8\end{array}$ & 33.3 & 21.2 & \\
\hline
\end{tabular}

第 2 表 臟器組織生青(兴琏)

\begin{tabular}{|c|c|c|c|c|c|c|c|c|c|c|c|c|c|c|c|}
\hline \multirow{3}{*}{ 家昰番寻 } & \multirow{3}{*}{$\begin{array}{l}\text { 血糖星 } \\
\mathrm{mg} / \mathrm{dl} \\
\left(\begin{array}{l}\text { 生存 } \\
\text { 日数 }\end{array}\right)\end{array}$} & \multirow{3}{*}{$\begin{array}{l:}\text { 原 } \\
\text { 面 } \\
\text { 積 }\end{array}$} & \multirow{3}{*}{$\begin{array}{l}\text { 平 } \\
\text { 均 }\end{array}$} & \multicolumn{4}{|c|}{ 恬 } & \multicolumn{2}{|l|}{18} & \multicolumn{2}{|l|}{$\theta$} & \multicolumn{2}{|c|}{ 数 } & & \\
\hline & & & & \multicolumn{2}{|c|}{ 第 } & \multicolumn{2}{|l|}{ 日 } & \multicolumn{2}{|c|}{ 符 } & \multicolumn{2}{|l|}{$2 \quad \mathrm{H}$} & \multicolumn{2}{|c|}{ 第 } & F & H \\
\hline & & & & 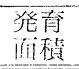 & 平均 & $\begin{array}{l}\text { 比較 } \\
\text { 成挍仳 }\end{array}$ & $\begin{array}{l}\text { 成晨 } \\
\text { 你数 }\end{array}$ & 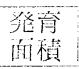 & $4 y_{3}$ & 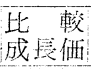 & $\begin{array}{l}\text { 成主 } \\
\text { 係数 }\end{array}$ & 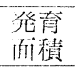 & 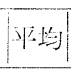 & 比較 & $\begin{array}{l}\text { 成悎 } \\
\text { 係数 }\end{array}$ \\
\hline No. 2 & $\begin{array}{l}520 \\
(7)\end{array}$ & $\begin{array}{l}1.5 \\
1.5 \\
1.4 \\
1.4 \\
1.4 \\
1.4\end{array}$ & 1.4 & $\begin{array}{l}58.7 \\
58.4 \\
57.4 \\
56.9 \\
56.3 \\
55.3\end{array}$ & 57.1 & 39.5 & 1.22 & $\begin{array}{l}71.1 \\
70.4 \\
69.7 \\
69.4 \\
68.7 \\
67.8\end{array}$ & 69.5 & 48.6 & 1.19 & $\begin{array}{l}76.2 \\
75.5 \\
74.8 \\
74.3 \\
73.4 \\
72.7\end{array}$ & 74.5 & 52.2 & 1.14 \\
\hline 対 照 & 106 & $\begin{array}{l}1.5 \\
1.4 \\
1.4 \\
1.4 \\
1.4 \\
1.3\end{array}$ & 1.4 & $\begin{array}{l}48.6 \\
47.9 \\
47.5 \\
46.7 \\
46.3 \\
46.5\end{array}$ & 47.1 & 32.6 & & $\begin{array}{l}60.5 \\
59.7 \\
59.1 \\
58.4 \\
57.7 \\
57.2\end{array}$ & 58.8 & 41.0 & & $\begin{array}{l}67.2 \\
66.6 \\
65.9 \\
65.5 \\
64.8 \\
63.9\end{array}$ & 65.7 & 45.9 & \\
\hline
\end{tabular}

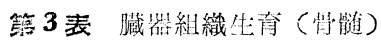

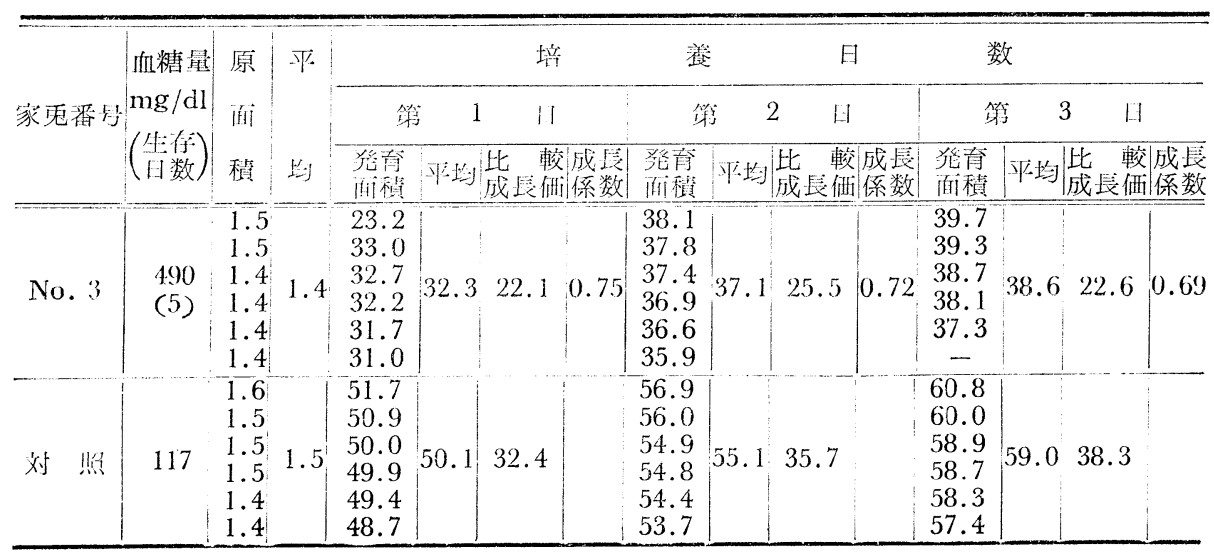




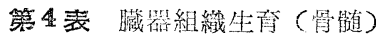

\begin{tabular}{|c|c|c|c|c|c|c|c|c|c|c|c|c|c|c|c|}
\hline \multirow{3}{*}{ 家医番号 } & \multirow{3}{*}{$\begin{array}{l}\text { 血穞星 } \\
\mathrm{mg} / \mathrm{dl} \\
\left(\begin{array}{l}\text { 生存 } \\
\text { 日数 }\end{array}\right)\end{array}$} & \multirow{3}{*}{$\begin{array}{l}\text { 原 } \\
\text { 面 } \\
\text { 積 }\end{array}$} & \multirow{3}{*}{ 平 } & \multicolumn{4}{|c|}{ 䏴 } & \multicolumn{2}{|l|}{ 锞 } & \multicolumn{2}{|c|}{ 日 } & \multicolumn{4}{|c|}{ 数 } \\
\hline & & & & \multicolumn{2}{|c|}{ 第 } & \multicolumn{2}{|l|}{ 日 } & \multicolumn{2}{|c|}{ 籍 } & \multicolumn{2}{|l|}{ 日 } & \multicolumn{2}{|c|}{ 第 } & 3 & 日 \\
\hline & & & & $\begin{array}{l}\text { 発育 } \\
\text { 偭樍 }\end{array}$ & 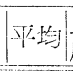 & 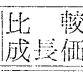 & 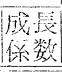 & $\begin{array}{l}\text { 等育 } \\
\text { 南禎 }\end{array}$ & 注均 & 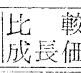 & 热数 & $\begin{array}{l}\text { 登育 } \\
\text { 面積 }\end{array}$ & 火均 & $\begin{array}{l}\text { 比軹 } \\
\text { 成莀佂 }\end{array}$ & 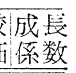 \\
\hline No. 4 & $\begin{array}{r}320 \\
(10)\end{array}$ & $\begin{array}{l}1.6 \\
1.6 \\
1.5 \\
1.5 \\
1.4 \\
1.3\end{array}$ & 1.5 & $\begin{array}{l}25.2 \\
24.6 \\
24.0 \\
23.0 \\
23.5 \\
22.1\end{array}$ & 23.7 & 14.8 & 0.81 & $\begin{array}{l}33.8 \\
33.0 \\
32.3 \\
31.7 \\
30.9 \\
29.7\end{array}$ & 31.9 & 20.3 & 0.82 & $\begin{array}{l}35.8 \\
35.0 \\
34.3 \\
33.4 \\
32.7 \\
31.7\end{array}$ & 33.8 & 21.5 & 0.77 \\
\hline 刘 照 & 98 & \begin{tabular}{l|}
1.6 \\
1.5 \\
1.5 \\
1.4 \\
1.3 \\
1.3
\end{tabular} & 1.4 & $\begin{array}{l}28.6 \\
27.9 \\
27.2 \\
26.7 \\
26.0 \\
25.0\end{array}$ & 26.9 & 18.2 & & $\begin{array}{l}38.1 \\
37.1 \\
36.6 \\
35.6 \\
35.0 \\
33.7\end{array}$ & 36.0 & 24.7 & & $\begin{array}{l}42.6 \\
41.5 \\
30.9 \\
30.0 \\
38.9 \\
37.7\end{array}$ & 40.3 & 27.8 & \\
\hline
\end{tabular}

第 5 表 臟器組織生青(骨熥)

\begin{tabular}{|c|c|c|c|c|c|c|c|c|c|c|c|c|c|c|c|}
\hline \multirow{3}{*}{ 家鬼番号 } & \multirow{3}{*}{$\begin{array}{l}\text { 血糖量 } \\
\mathrm{mg} / \mathrm{dl} \\
(\text { 生存 } \\
\text { 日数 }\end{array}$} & \multirow{3}{*}{$\begin{array}{l}\text { 原 } \\
\text { 面 } \\
\text { 積 }\end{array}$} & \multirow{3}{*}{ 均 } & \multicolumn{4}{|c|}{ 隐 } & \multicolumn{2}{|c|}{ 養 } & \multicolumn{2}{|c|}{ 日 } & \multicolumn{4}{|c|}{ 数 } \\
\hline & & & & \multicolumn{2}{|c|}{ 第 } & 1 & & \multicolumn{2}{|c|}{ 第 } & \multicolumn{2}{|l|}{1} & \multicolumn{2}{|c|}{ 第 } & $E$ & \\
\hline & & & & $\begin{array}{l}\text { 篗育 } \\
\text { 面積 } \\
\end{array}$ & 平均 & 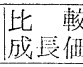 & 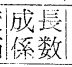 & 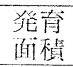 & 平均 & $\begin{array}{l}\text { 比 颙 } \\
\text { 成長佃 }\end{array}$ & $\begin{array}{l}\text { 成是 } \\
\text { 係数 }\end{array}$ & $\begin{array}{l}\text { 発青 } \\
\text { 面皘 }\end{array}$ & 话均 & 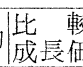 & $\begin{array}{l}\text { 效成長 } \\
\text { it係数 }\end{array}$ \\
\hline No. 5 & $\begin{array}{r}510 \\
(14)\end{array}$ & $\begin{array}{l}1.2 \\
1.2 \\
1.1 \\
1.1 \\
1.0 \\
1.0\end{array}$ & 1.1 & $\begin{array}{l}21.5 \\
20.9 \\
20.4 \\
19.6 \\
19.2 \\
18.9\end{array}$ & 20.1 & 17.3 & 0.85 & $\begin{array}{l}30.6 \\
29.9 \\
29.2 \\
28.3 \\
27.8 \\
27.4\end{array}$ & 28.9 & 25.3 & 0.89 & $\begin{array}{l}33.2 \\
32.4 \\
31.8 \\
30.9 \\
30.3 \\
29.7\end{array}$ & 31.4 & $\begin{array}{l}427.5 \\
\end{array}$ & 0.87 \\
\hline 刘 照 & 120 & $\begin{array}{l}1.2 \\
1.1 \\
1.1 \\
1.1 \\
1.0 \\
1.0\end{array}$ & 1.1 & $\begin{array}{l}24.9 \\
24.3 \\
23.6 \\
23.1 \\
22.6 \\
21.8\end{array}$ & 23.4 & 20.3 & & $\begin{array}{l}34.0 \\
33.4 \\
32.7 \\
31.9 \\
31.3 \\
30.4\end{array}$ & 32.3 & 28.4 & & $\begin{array}{l}38.1 \\
37.4 \\
36.4 \\
35.3 \\
34.6 \\
33.6\end{array}$ & 35.9 & 931.6 & \\
\hline
\end{tabular}

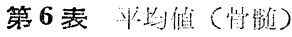

\begin{tabular}{|c|c|c|c|c|}
\hline \multirow{2}{*}{$\begin{array}{l}\text { 家鬼 } \\
\text { 番耍 }\end{array}$} & \multirow{2}{*}{$\begin{array}{l}\text { 血糖量 } \\
\mathrm{mg} / \mathrm{dl}\end{array}$} & 塪 & 維 & 数 \\
\hline & & 第 1 日 & 第 2 日 & 第 3 日 \\
\hline 1 & 400 & 1.14 & 1.08 & 1.08 \\
\hline 2 & 520 & 1.22 & 1.19 & 1.14 \\
\hline 3 & 490 & 0.75 & 0.72 & 0.69 \\
\hline 4 & 320 & 0.81 & 0.82 & 0.77 \\
\hline 5 & 510 & 0.85 & 0.89 & $0.8^{\prime} 7$ \\
\hline 平均 & & 0.95 & 0.94 & 0.91 \\
\hline
\end{tabular}

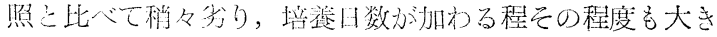

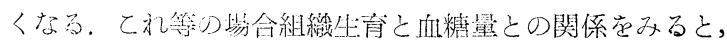

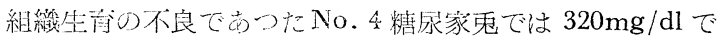
あり，組織生育の良好であつたNo. 2 糖尿家鬼の血糖量は $520 \mathrm{mg} / \mathrm{dl}$ であり，組織生肖と血糖且との間には密接な関

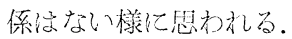

\section{第 2 項 脾}

菨 7 ～12亿示す如く, 糖永家鬼脾㵴の生育は正常のもの に比心般に稍々劣る傾问にある。No.11，16糖㽷家鬼組

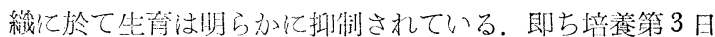

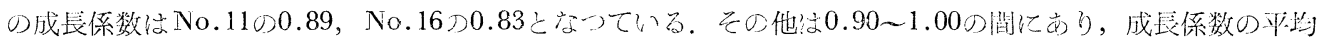

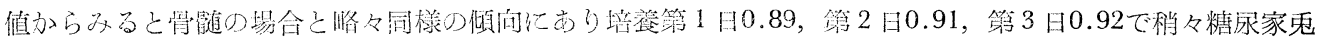
に於て組變生育俚劣る。

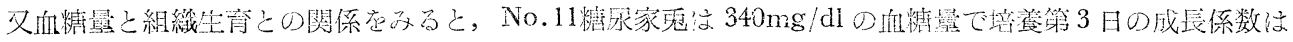

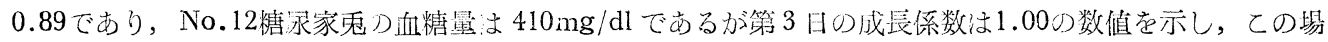


第 7 表 臟器組織生育 (脾臟)

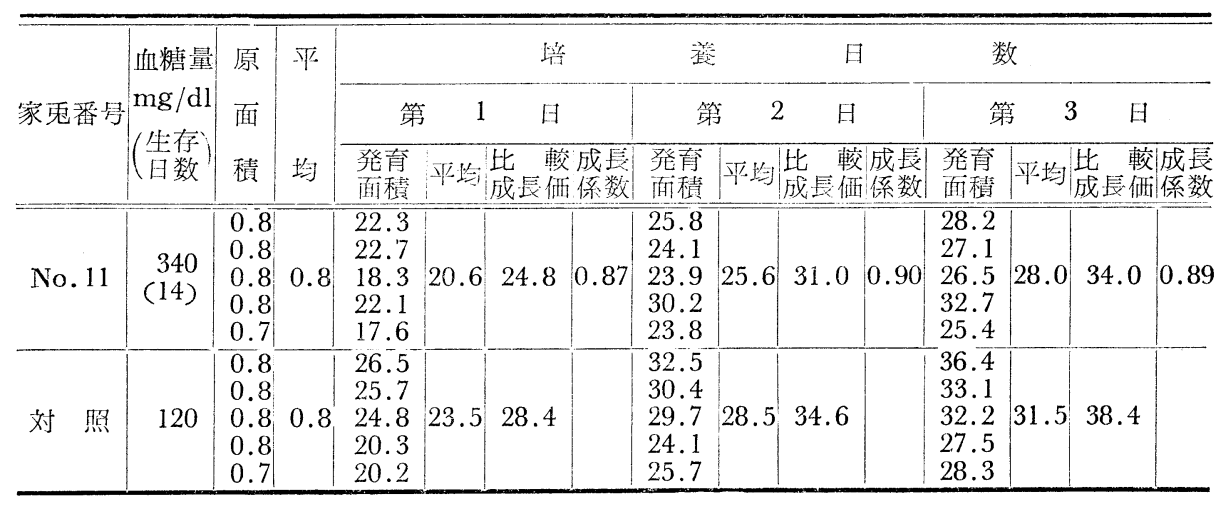

第 8 表 䑏器組織生青 (脾蔵)

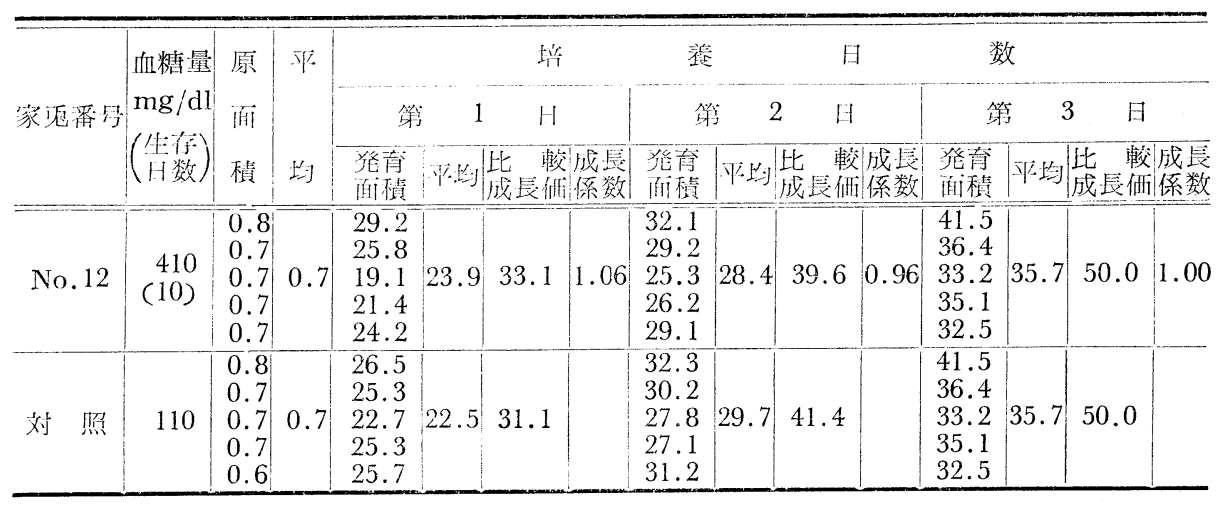

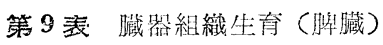

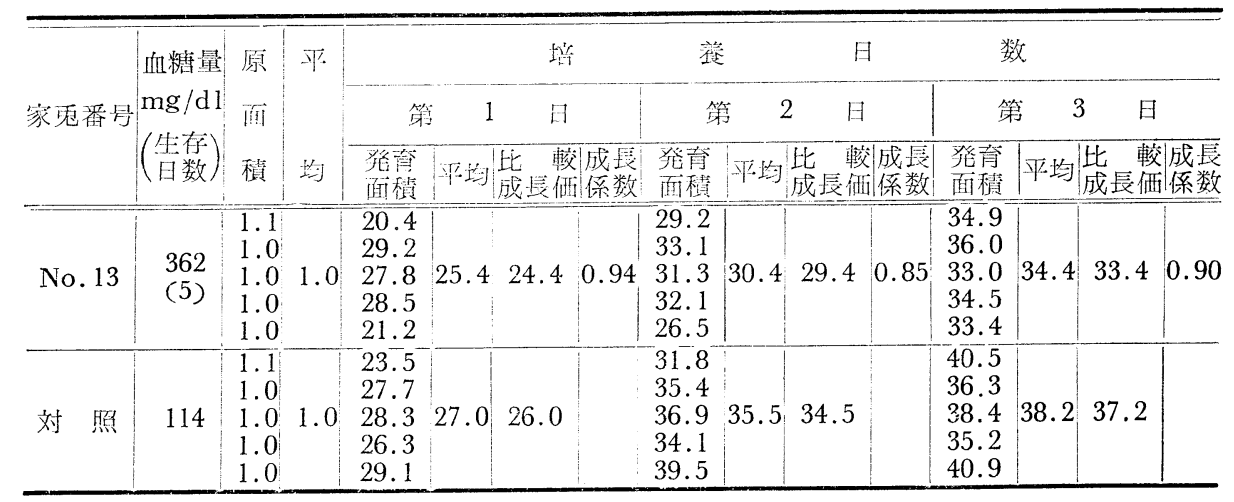


第10表 臟器組織生育(脾藏)

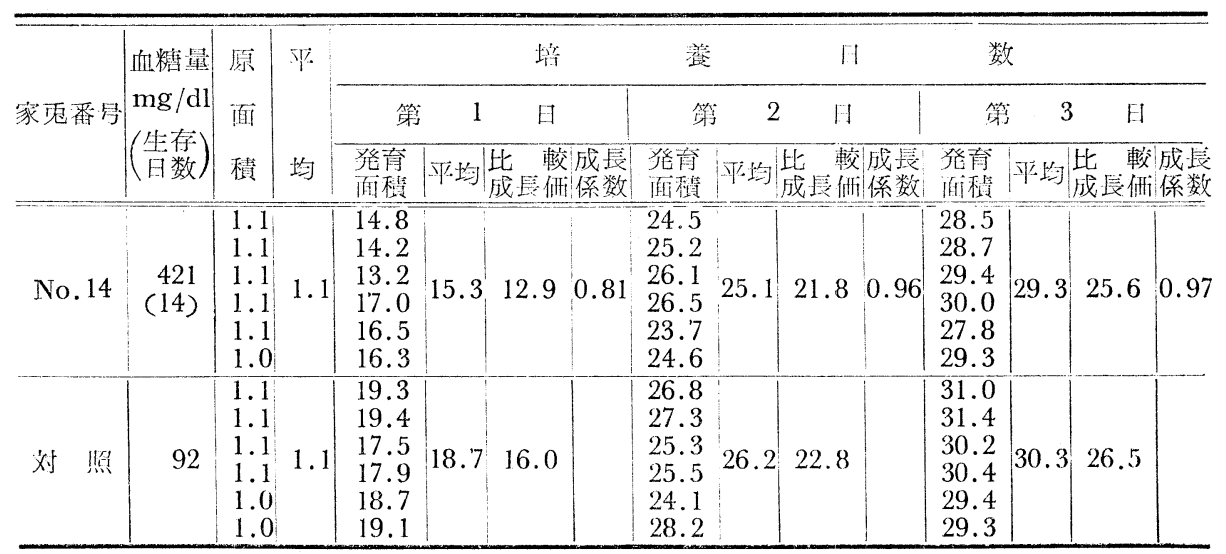

第11表 臟器組織生战(脾臟)

\begin{tabular}{|c|c|c|c|c|c|c|c|c|c|c|c|c|c|c|c|}
\hline \multirow{3}{*}{ 家洰䊉号 } & \multirow{3}{*}{$\begin{array}{l}\text { 血糖昆 } \\
\mathrm{mg} / \mathrm{dl} \\
\left(\begin{array}{l}\text { 特: } \\
\mathrm{H} \text { 数 }\end{array}\right)\end{array}$} & \multirow{3}{*}{$\begin{array}{l}\text { 原 } \\
\text { 闻 } \\
\text { 積 }\end{array}$} & \multirow{3}{*}{$\begin{array}{l}\text { \% } \\
\text { 桨 }\end{array}$} & \multicolumn{4}{|c|}{ 䏴 } & \multicolumn{2}{|c|}{ 怔 } & \multicolumn{2}{|c|}{11} & \multicolumn{4}{|c|}{ 数 } \\
\hline & & & & \multicolumn{2}{|c|}{ 符 } & \multicolumn{2}{|l|}{$H$} & \multicolumn{2}{|c|}{ 第 2} & \multicolumn{2}{|l|}{11} & \multicolumn{2}{|c|}{ 籍 } & \multicolumn{2}{|c|}{3} \\
\hline & & & & $\begin{array}{l}\text { 発青 } \\
\text { 㨁棈 }\end{array}$ & F坞 & $\begin{array}{l}\text { 比較 } \\
\text { 战长湖 }\end{array}$ & 成展 & $\begin{array}{l}\text { 発育 } \\
\text { 而棈 }\end{array}$ & 和均 & $\begin{array}{l}\text { 比敖 } \\
\text { 成长湖 }\end{array}$ & 成表 & $\begin{array}{l}\text { 発育 } \\
\text { 闻梘 }\end{array}$ & 性诗 & $\begin{array}{l}\text { 比較 } \\
\text { 成受佰 }\end{array}$ & 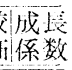 \\
\hline No. 15 & $\begin{array}{r}312 \\
(10)\end{array}$ & $\begin{array}{l}1.0 \\
0.9 \\
0.9 \\
0.9 \\
0.9 \\
0.9\end{array}$ & 0.9 & $\begin{array}{l}19.6 \\
20.9 \\
19.0 \\
19.5 \\
22.0 \\
21.6\end{array}$ & 20.4 & 21.7 & 0.89 & $\begin{array}{l}31.0 \\
30.3 \\
31.5 \\
29.2 \\
27.4 \\
28.5\end{array}$ & 29.7 & 32.0 & 0.94 & $\begin{array}{l}36.0 \\
37.5 \\
40.2 \\
38.5 \\
39.2 \\
36.3\end{array}$ & 38.0 & 41.2 & 0.92 \\
\hline 対 䛇 & 134 & $\begin{array}{l}0.9 \\
0.9 \\
0.9 \\
0.9 \\
0.9 \\
0.9\end{array}$ & 0.9 & $\begin{array}{l}22.5 \\
23.0 \\
24.4 \\
21.6 \\
21.4 \\
20.2\end{array}$ & 22.0 & 24.3 & & $\begin{array}{l}31.8 \\
31.5 \\
32.2 \\
33.0 \\
32.5 \\
29.1\end{array}$ & 31.4 & 433.9 & & $\begin{array}{l}40.0 \\
41.3 \\
40.7 \\
41.8 \\
39.4 \\
38.7\end{array}$ & 40.3 & 43.8 & \\
\hline
\end{tabular}

第12表 臟器組織生育 (脾臟)

\begin{tabular}{|c|c|c|c|c|c|c|c|c|c|c|c|c|c|c|c|}
\hline \multirow{3}{*}{ 家鬼番号 } & \multirow{3}{*}{$\mid \begin{array}{l}\text { Ifll糖量 } \\
\mathrm{mg} / \mathrm{dl} \\
\left(\begin{array}{l}\text { 生存 } \\
\text { 日数 }\end{array}\right)\end{array}$} & \multirow{3}{*}{\begin{tabular}{l|} 
原 \\
括 \\
積
\end{tabular}} & \multirow{3}{*}{ 平 } & \multicolumn{4}{|c|}{ 培 } & \multicolumn{2}{|c|}{ 慕 } & \multicolumn{2}{|c|}{ 日 } & \multicolumn{2}{|c|}{ 数 } & & \\
\hline & & & & \multicolumn{2}{|c|}{ 筙 } & \multicolumn{2}{|l|}{ H } & \multicolumn{2}{|c|}{ 第 } & F & & \multicolumn{2}{|c|}{ 第 } & 3 & \\
\hline & & & & $\begin{array}{l}\text { 発育 } \\
\text { 䤃程 }\end{array}$ & 平均 & $\begin{array}{l}\text { 比 較 } \\
\text { 成表価 }\end{array}$ & 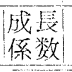 & $\begin{array}{l}\text { 発育 } \\
\text { 面棈 }\end{array}$ & 情均 & $\begin{array}{l}\text { 比較 } \\
\text { 成㒸価 }\end{array}$ & 成典 & $\begin{array}{l}\text { 発育 } \\
\text { 面栍 }\end{array}$ & 平均 & $\begin{array}{l}\text { 此 較 } \\
\text { 成辰枿 } \\
\end{array}$ & $\begin{array}{l}\text { 成長 } \\
\text { in 係数 }\end{array}$ \\
\hline No. 16 & $\begin{array}{r}320 \\
(15)\end{array}$ & $\begin{array}{l}0.8 \\
0.7 \\
0.7 \\
0.7 \\
0.6\end{array}$ & 0.7 & $\begin{array}{l}19.1 \\
20.3 \\
18.6 \\
19.2 \\
20.7\end{array}$ & 19.6 & 27.0 & 0.79 & $\begin{array}{l}26.3 \\
26.2 \\
27.5 \\
29.0 \\
27.4\end{array}$ & 26.7 & 37.1 & 0.82 & $\begin{array}{l}32.5 \\
33.1 \\
34.6 \\
32.3 \\
35.2\end{array}$ & 33.5 & 46.9 & 0.83 \\
\hline 対 照 & 115 & $\begin{array}{l}0.8 \\
0.8 \\
0.7 \\
0.7 \\
0.7\end{array}$ & 0.7 & $\begin{array}{l}25.3 \\
25.9 \\
27.3 \\
24.6 \\
24.4 \\
\end{array}$ & 24.6 & 34.1 & & $\begin{array}{l}34.8 \\
34.3 \\
31.9 \\
32.3 \\
30.5 \\
\end{array}$ & 32.3 & 45.1 & & $\begin{array}{l}41.2 \\
40.9 \\
40.7 \\
40.1 \\
39.2 \\
\end{array}$ & 40.4 & 56.7 & \\
\hline
\end{tabular}


第13表 平均值 (脾藏)

\begin{tabular}{|c|c|c|c|c|}
\hline \multirow{2}{*}{$\begin{array}{l}\text { 家鬼 } \\
\text { 番号 }\end{array}$} & \multirow{2}{*}{$\begin{array}{l}\text { 血精量 } \\
\mathrm{mg} / \mathrm{dl}\end{array}$} & 培 & 養 & 数 \\
\hline & & 第 1 日 & 第 2 日 & 第 3 日 \\
\hline 11 & 340 & 0.87 & 0.90 & 0.89 \\
\hline 12 & 410 & 1.06 & 0.96 & 1.00 \\
\hline 13 & 362 & 0.94 & 0.85 & 0.90 \\
\hline 14 & 421 & 0.81 & 0.96 & 0.97 \\
\hline 15 & 312 & 0.89 & 0.94 & 0.92 \\
\hline 16 & 320 & 0.72 & 0.82 & 0.83 \\
\hline 平均 & & 0.89 & 0.91 & 0.92 \\
\hline
\end{tabular}

命にも骨髄組織と同樣に糖尿家兄血糖量と組織生育との間 には密接な関係㤂ないと考えられる。

\section{第 2 節「ア糖尿家兔血清の骨髓及び脾臟組織 生育に及ぼす影響}

糖疗病思者血清中に組繶生育至障碍する因子のあること

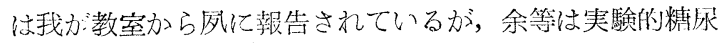

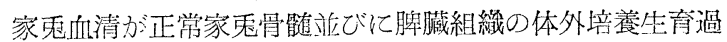

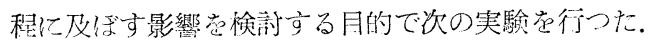

\section{第 1 項 正常家鬼骨髓組織培䔆時「ア、糖尿家鬼 血清を添加した場合}

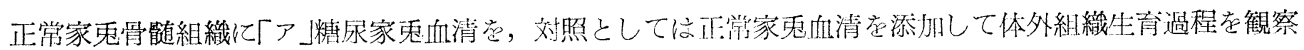

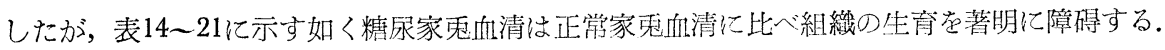

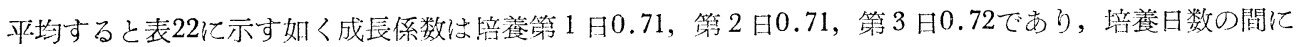

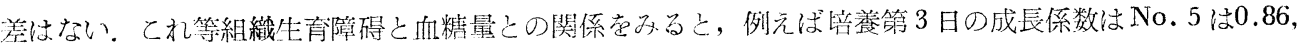

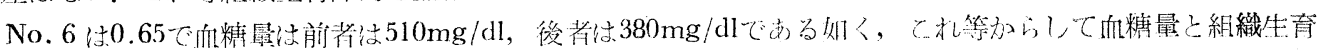

第14表 健管組織に家鬼血清添加した場合（骨髄）

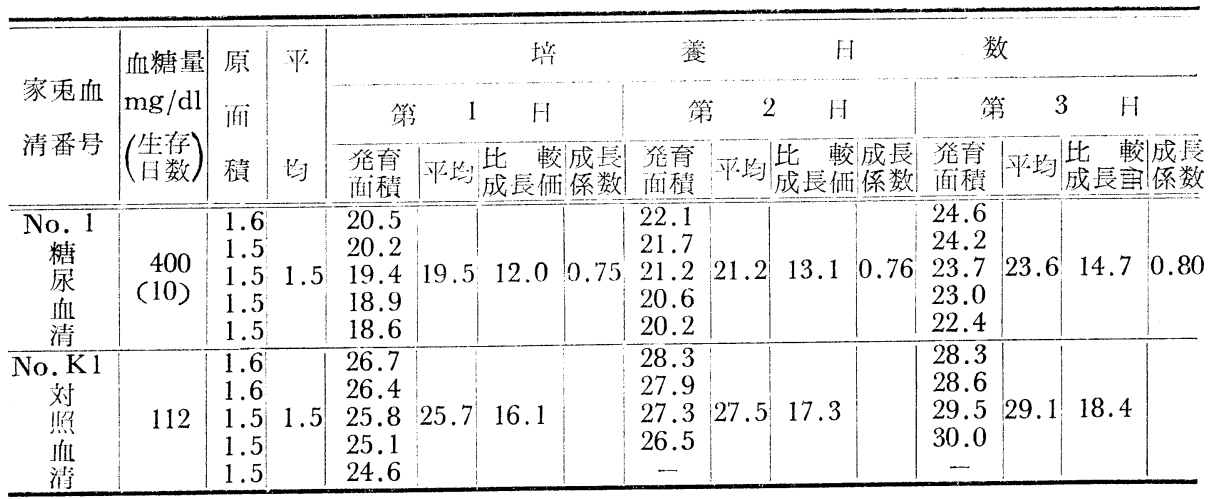

第15表 健常組織に家鬼血清添加した場合(骨髄)

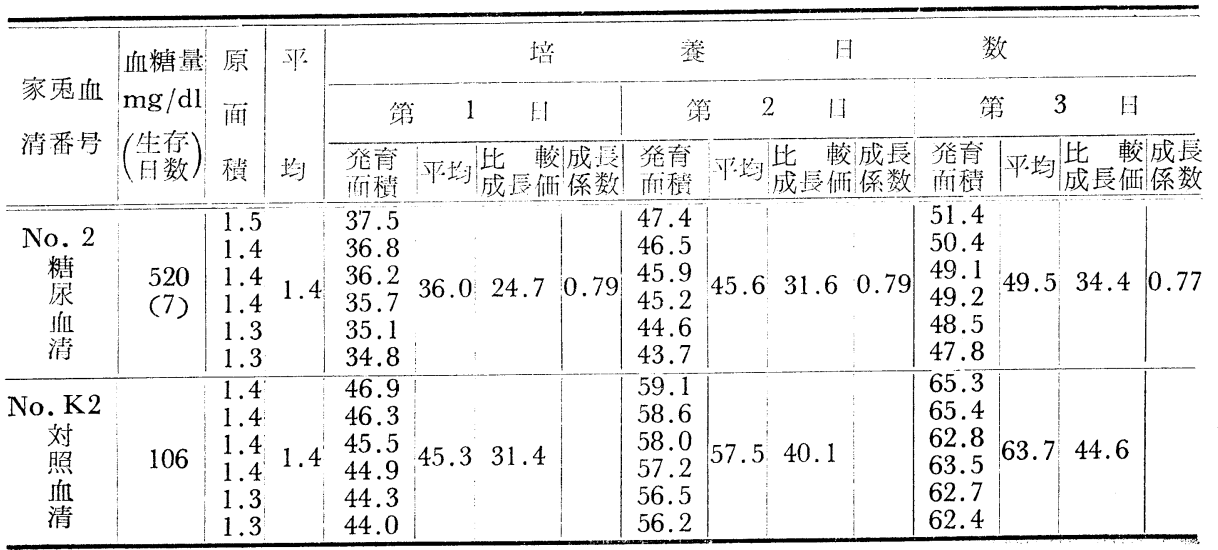




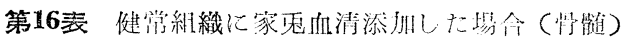

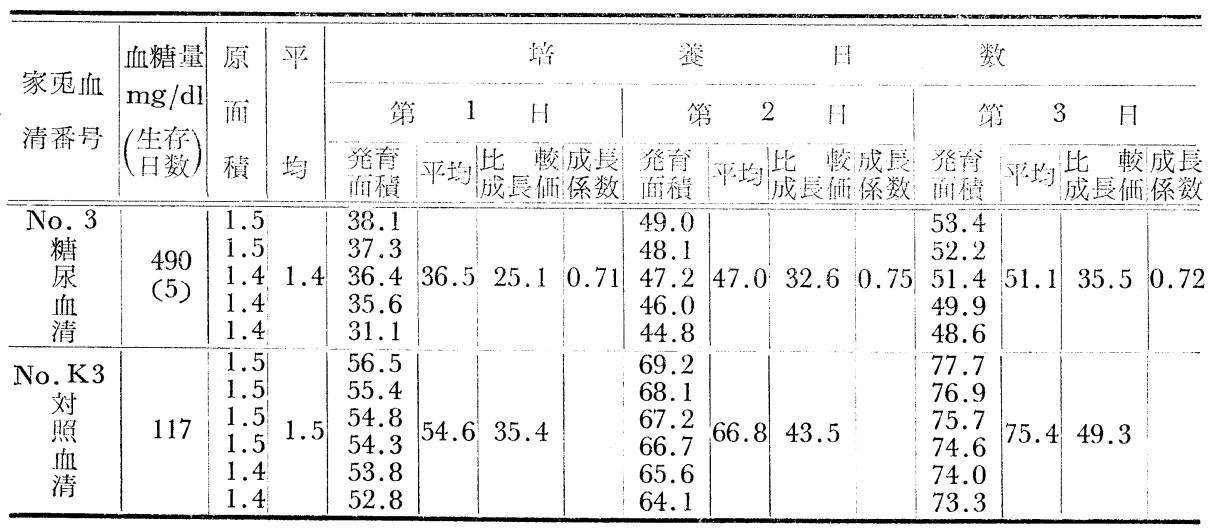

第17表 健常組織に家鬼血清添加した崵侖(罚髄)

\begin{tabular}{|c|c|c|c|c|c|c|c|c|c|c|c|c|c|c|c|}
\hline \multirow{3}{*}{$\begin{array}{l}\text { 家䨤血 } \\
\text { 浖番夏 }\end{array}$} & \multirow{3}{*}{$\left.\begin{array}{l}\text { 血糖星 } \\
\mathrm{mg} / \mathrm{dl} \\
(\text { 生存 } \\
\text { 数 }\end{array}\right)$} & \multirow{3}{*}{$\begin{array}{l}\text { 原 } \\
\text { 面 } \\
\text { 䩀 }\end{array}$} & \multirow{3}{*}{ 平 } & \multicolumn{4}{|c|}{ 培 } & \multicolumn{2}{|c|}{ 養 } & \multicolumn{2}{|c|}{ 日 } & \multicolumn{4}{|c|}{ 数 } \\
\hline & & & & \multicolumn{2}{|c|}{ 第 } & 1 & & \multicolumn{2}{|c|}{ 第 } & \multicolumn{2}{|c|}{2} & \multicolumn{2}{|c|}{ 第 } & 1 & H \\
\hline & & & & $\begin{array}{l}\text { 発育 } \\
\text { 面積 }\end{array}$ & 平地 & $\begin{array}{l}\text { 比軹 } \\
\text { 成走皿 }\end{array}$ & 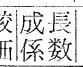 & $\begin{array}{l}\text { 発育 } \\
\text { 面䄳 }\end{array}$ & 妆均 & 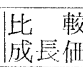 & 成喜 & $\begin{array}{l}\text { 笔青 } \\
\text { 面積 }\end{array}$ & 平均 & 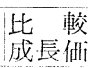 & $\begin{array}{l}\text { 訚成長 } \\
\text { Hif 係数 }\end{array}$ \\
\hline 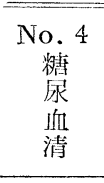 & $\begin{array}{r}320 \\
(10)\end{array}$ & $\begin{array}{l}1.6 \\
1.5 \\
1.5 \\
1.4 \\
1.3 \\
1.3\end{array}$ & 1.4 & $\begin{array}{l}20.3 \\
29.8 \\
29.4 \\
28.9 \\
28.4 \\
27.8 \\
\end{array}$ & 19.1 & 12.6 & 0.72 & $\begin{array}{l}24.9 \\
24.3 \\
23.6 \\
23.0 \\
22.4 \\
22.0 \\
\end{array}$ & 23.4 & 15.7 & 0.69 & $\begin{array}{l}26.6 \\
25.9 \\
25.2 \\
24.5 \\
24.1 \\
23.3\end{array}$ & 24.9 & 16.8 & 0.68 \\
\hline $\begin{array}{c}\text { No. K4 } \\
\text { 対 } \\
\text { 照 } \\
\text { 血 } \\
\text { 清 } \\
\end{array}$ & 98 & $\begin{array}{l}1.5 \\
1.5 \\
1.4 \\
1.4 \\
1.4 \\
1.3\end{array}$ & 1.4 & $\begin{array}{l}27.3 \\
27.0 \\
26.2 \\
25.5 \\
24.9 \\
24.1\end{array}$ & 25.8 & 17.4 & & $\begin{array}{l}35.1 \\
34.2 \\
33.4 \\
32.8 \\
31.9 \\
31.2\end{array}$ & 33.1 & 22.6 & & $\begin{array}{l}38.3 \\
37.6 \\
36.4 \\
35.5 \\
34.4 \\
33.7\end{array}$ & 35.9 & 24.6 & \\
\hline
\end{tabular}

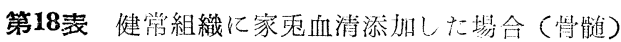

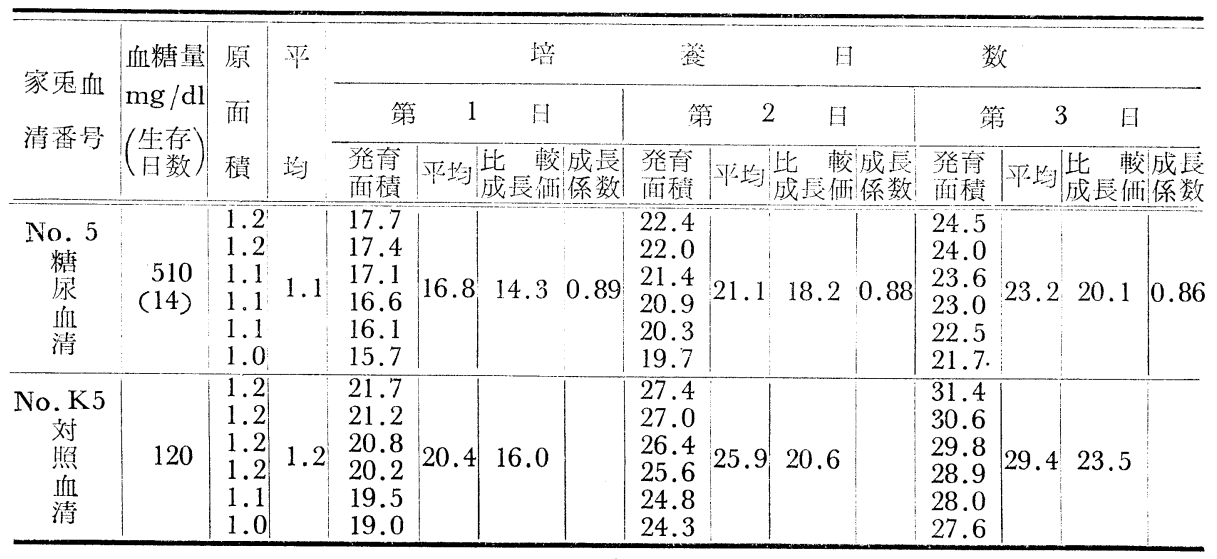




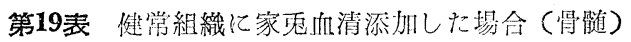

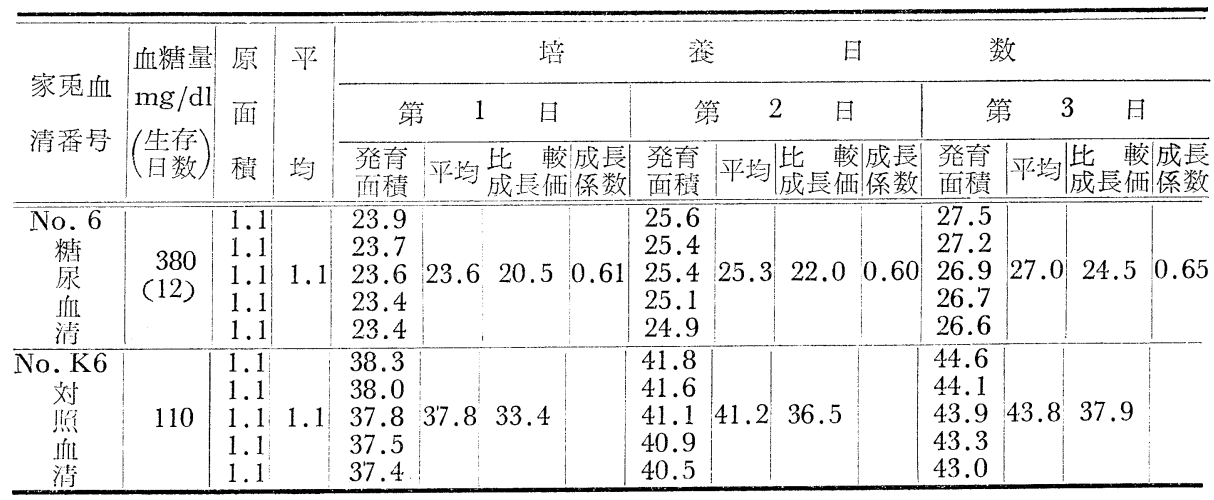

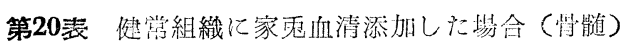

\begin{tabular}{|c|c|c|c|c|c|c|c|c|c|c|c|c|c|c|c|}
\hline \multirow{3}{*}{ 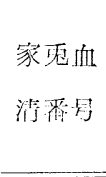 } & \multirow{3}{*}{$\begin{array}{l}\text { 血粕基 } \\
\mathrm{mg} / \mathrm{dl} \\
\left(\frac{\text { 生存 }}{\mathrm{G}}\right)\end{array}$} & \multirow{3}{*}{$\begin{array}{l}\text { 原 } \\
\text { 画 } \\
\text { 程 }\end{array}$} & \multirow{3}{*}{ 店 } & \multicolumn{4}{|c|}{ 培 } & \multicolumn{2}{|c|}{ 峜 } & \multicolumn{2}{|c|}{ 日 } & \multicolumn{2}{|c|}{ 数 } & \multirow[b]{2}{*}{ 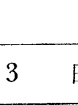 } & \multirow[b]{2}{*}{ 日 } \\
\hline & & & & \multicolumn{2}{|c|}{ 第 } & \multicolumn{2}{|c|}{ 口 } & \multicolumn{2}{|c|}{ 第 } & \multicolumn{2}{|c|}{2} & \multicolumn{2}{|c|}{ 第 } & & \\
\hline & & & & $\begin{array}{l}\text { 無育 } \\
\text { 面積 }\end{array}$ & 原均 & $\begin{array}{l}\text { 比 軦 } \\
\text { 成景倠 }\end{array}$ & $\begin{array}{l}\text { 㳇成厓 } \\
\text { 耐係数 }\end{array}$ & $\begin{array}{l}\text { 登育 } \\
\text { 而䅡 } \\
\end{array}$ & 平均 & $\begin{array}{l}\text { 比 曹 } \\
\text { 成是伯 }\end{array}$ & $\begin{array}{l}\text { 芢成長 } \\
\text { 沙係 }\end{array}$ & $\begin{array}{l}\text { 発育 } \\
\text { 面精 }\end{array}$ & 平均 & $\begin{array}{ll}\text { 此 } & \text { 輬 } \\
\text { 成長佂 }\end{array}$ & $\begin{array}{l}\text { 效成長 } \\
\mathrm{fif} \text { 数 }\end{array}$ \\
\hline 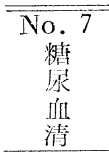 & $\begin{array}{r}450 \\
(10)\end{array}$ & $\begin{array}{l}1.1 \\
1.0 \\
1.0 \\
1.0 \\
1.0\end{array}$ & 1.0 & $\begin{array}{l}22.8 \\
22.8 \\
22.6 \\
22.5 \\
22.4\end{array}$ & 22.6 & 21.6 & 0.60 & $\begin{array}{l}24.7 \\
24.5 \\
24.4 \\
24.2 \\
24.1\end{array}$ & 24.4 & 23.4 & 0.63 & $\begin{array}{l}25.6 \\
25.4 \\
25.3 \\
25.0 \\
24.9 \\
\end{array}$ & 25.2 & 24.2 & 0.64 \\
\hline 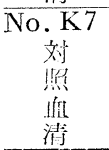 & 132 & $\begin{array}{l}1.0 \\
1.0 \\
1.0 \\
1.0 \\
1.0\end{array}$ & 1.0 & $\begin{array}{l}35.6 \\
35.5 \\
35.3 \\
35.2 \\
34.9\end{array}$ & 35.3 & 34.3 & & $\begin{array}{l}38.7 \\
38.5 \\
38.1 \\
38.0 \\
37.6\end{array}$ & 38.2 & 37.2 & & $\begin{array}{l}40.9 \\
40.8 \\
40.3 \\
40.0 \\
39.6 \\
\end{array}$ & 40.3 & 39.3 & \\
\hline
\end{tabular}

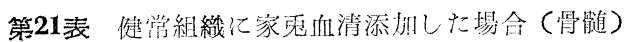

\begin{tabular}{|c|c|c|c|c|c|c|c|c|c|c|c|c|c|c|c|}
\hline \multirow{3}{*}{ 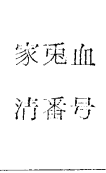 } & \multirow{3}{*}{ 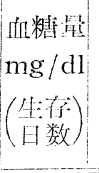 } & \multirow{3}{*}{ 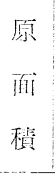 } & \multirow{3}{*}{ 平 } & \multicolumn{4}{|c|}{ 隚 } & \multicolumn{3}{|c|}{ 跸 } & \multicolumn{2}{|c|}{ 日 } & \multicolumn{3}{|c|}{ 数 } \\
\hline & & & & \multicolumn{2}{|c|}{ 第 } & \multicolumn{2}{|c|}{$1 日$} & \multicolumn{3}{|c|}{ 第 } & 日 & \multicolumn{2}{|c|}{ 第 } & \multicolumn{2}{|c|}{ 日 } \\
\hline & & & & $\begin{array}{l}\text { 炎育 } \\
\text { 而督 }\end{array}$ & 平均 & $\begin{array}{l}\text { 比㫫 } \\
\text { 成莀俏 }\end{array}$ & 係数 & $\begin{array}{l}\text { 発青 } \\
\text { 面積 }\end{array}$ & 平均 & $\begin{array}{l}\text { 比輤 } \\
\text { 成退们 }\end{array}$ & 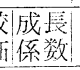 & 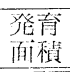 & 平地 & 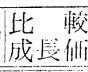 & 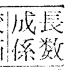 \\
\hline $\begin{array}{c}\text { No. } 8 \\
\text { 䊅 } \\
\text { 水 } \\
\text { IfIL } \\
\text { 湝 } \\
\end{array}$ & $\begin{array}{l}410 \\
(7)\end{array}$ & $\begin{array}{l}1.1 \\
1.1 \\
1.1 \\
1.1 \\
1.0\end{array}$ & 1.1 & $\begin{array}{l}23.6 \\
23.6 \\
23.4 \\
23.3 \\
23.1\end{array}$ & 23.4 & 20.3 & 0.57 & $\begin{array}{l}25.6 \\
25.6 \\
25.3 \\
25.2 \\
24.9\end{array}$ & 25.3 & 22.0 & 0.58 & $\begin{array}{l}28.1 \\
27.8 \\
27.7 \\
27.4 \\
27.2\end{array}$ & 27.6 & 24.1 & 0.60 \\
\hline 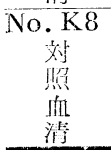 & 95 & $\begin{array}{l}1.1 \\
1.0 \\
1.0 \\
1.0 \\
1.0\end{array}$ & 1.0 & $\begin{array}{l}37.1 \\
36.9 \\
36.5 \\
36.5 \\
36.2\end{array}$ & 36.6 & 35.6 & & $\begin{array}{l}39.8 \\
39.5 \\
39.1 \\
38.8 \\
38.6 \\
\end{array}$ & 39.2 & 38.2 & & $\begin{array}{l}41.9 \\
41.4 \\
41.2 \\
40.8 \\
40.6 \\
\end{array}$ & 41.2 & 40.2 & \\
\hline
\end{tabular}


第22表 原均值(骨制)

\begin{tabular}{|c|c|c|c|c|}
\hline \multirow{2}{*}{$\begin{array}{l}\text { 家鬼血 } \\
\text { 清番号 }\end{array}$} & \multirow{2}{*}{$\begin{array}{l}\text { 血糖量 } \\
\mathrm{mg} / \mathrm{dl}\end{array}$} & 㩁 & 篒 & 数 \\
\hline & & 第 1 日 & 第 2 日 & 第 3 日 \\
\hline 1 & 400 & 0.75 & 0.76 & 0.80 \\
\hline 2 & 520 & 0.79 & 0.79 & 0.77 \\
\hline 3 & 490 & 0.71 & 0.75 & 0.72 \\
\hline 4 & 320 & 0.72 & 0.69 & 0.68 \\
\hline 5 & 510 & 0.89 & 0.88 & 0.86 \\
\hline 6 & 380 & 0.61 & 0.60 & 0.65 \\
\hline 7 & 450 & 0.60 & 0.63 & 0.64 \\
\hline 8 & 410 & 0.57 & 0.58 & 0.60 \\
\hline 平均 & & 0.71 & 0.71 & 0.72 \\
\hline
\end{tabular}

抑制度とは密接な関係はないものと思われる。

\section{第 2 項 正常家鬼脾恶組織培萫時「ア「糖尿家鬼 血清を添加した場合}

実験成績は表23～27亿示す如く骨笼の場合之略々同様の 成績を示し，しかも抑制度は骨㵦組織の場合よりも更に大 である. 即ち，5 例平均では表28亿示す如く成長係数は培 養第 1 日は 0.55 , 第 2 日0.63, 第 3 日0.63であり, 正常家 秋血清に比べ組織生育を著明に障碍される.

又組織生育障碍と血糖量との関係は骨髄の場合と同様密 接な関係は認め難い。

以上よりして「ア』糖尿家鬼血清には血糖量の如何に拘わ

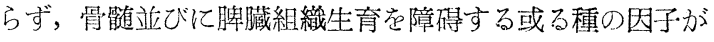
存在するものと考えられる。

策23表 健常組織に家鬼血清添加した埸命（脾蔵）

\begin{tabular}{|c|c|c|c|c|c|c|c|c|c|c|c|c|c|c|c|}
\hline \multirow{3}{*}{$\begin{array}{c}\text { 家鬼血 } \\
\text { 清番号 }\end{array}$} & \multirow{3}{*}{$\begin{array}{l}\text { fll糖量 } \\
\mathrm{mg} / \mathrm{dl} \\
(\text { 生存 } \\
\text { 日数 }\end{array}$} & \multirow{3}{*}{$\begin{array}{l}\text { 原 } \\
\text { 面 } \\
\text { 䅡 }\end{array}$} & \multirow{3}{*}{ 平 } & \multicolumn{4}{|c|}{ 培 } & \multicolumn{2}{|c|}{ 羑 } & \multicolumn{2}{|c|}{ 日 } & \multicolumn{4}{|c|}{ 数 } \\
\hline & & & & \multicolumn{2}{|c|}{ 第 } & \multicolumn{2}{|l|}{ H } & \multicolumn{2}{|c|}{ 第 } & \multicolumn{2}{|c|}{$H$} & \multicolumn{2}{|c|}{ 第 } & \multicolumn{2}{|l|}{$H$} \\
\hline & & & & $\begin{array}{l}\text { 発青 } \\
\text { 面程 }\end{array}$ & 佇均 & $\begin{array}{l}\text { 比 軦 } \\
\text { 成長俩 }\end{array}$ & 成長 & $\begin{array}{l}\text { 発育 } \\
\text { 面積 }\end{array}$ & 平均 & $\begin{array}{l}\text { 比軹 } \\
\text { 成長佂 }\end{array}$ & 成長 & $\begin{array}{l}\text { 発育 } \\
\text { 面積 }\end{array}$ & 平均 & $\begin{array}{l}\text { 比 較 } \\
\text { 成長洒 }\end{array}$ & $\begin{array}{l}\text { 成長 } \\
\text { 係数 }\end{array}$ \\
\hline $\begin{array}{c}\text { No.11 } \\
\text { 糖 } \\
\text { 㽷 } \\
\text { 血 } \\
\text { 清 }\end{array}$ & $\begin{array}{l}340 \\
\text { (14) }\end{array}$ & $\begin{array}{l}1.1 \\
1.0 \\
1.0 \\
1.0 \\
1.0\end{array}$ & 1.0 & $\begin{array}{l}16.8 \\
20.5 \\
21.0 \\
19.0 \\
23.5\end{array}$ & 20.2 & 19.2 & 0.68 & $\begin{array}{l}20.6 \\
27.2 \\
24.8 \\
23.5 \\
29.5\end{array}$ & 25.1 & 24.1 & 0.69 & $\begin{array}{l}33.9 \\
30.8 \\
28.4 \\
27.4 \\
30.5\end{array}$ & 28.2 & 27.2 & 0.71 \\
\hline 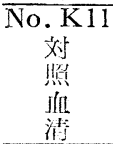 & 120 & $\begin{array}{l}1.0 \\
1.0 \\
1.0 \\
1.0 \\
0.9\end{array}$ & 1.0 & $\begin{array}{l}30.2 \\
34.2 \\
28.5 \\
27.0 \\
25.7\end{array}$ & 29.1 & 28.1 & & $\begin{array}{l}37.5 \\
41.2 \\
34.3 \\
35.1 \\
31.3\end{array}$ & 35.9 & 34.9 & & $\begin{array}{l}40.2 \\
43.5 \\
39.1 \\
37.2 \\
36.5\end{array}$ & 39.3 & 38.3 & \\
\hline
\end{tabular}

第24表 健常組織に家鬼血清添加した場合（䛲藏）

\begin{tabular}{|c|c|c|c|c|c|c|c|c|c|c|c|c|c|c|c|}
\hline \multirow{3}{*}{$\begin{array}{l}\text { 家香血 } \\
\text { 清番号 }\end{array}$} & \multirow{3}{*}{$\begin{array}{l}\text { fit 糖量 } \\
\mathrm{mg} / \mathrm{dl} \\
(\text { 生存 } \\
\text { 日数) }\end{array}$} & \multirow{3}{*}{$\begin{array}{l}\text { 原 } \\
\text { 面 } \\
\text { 積 }\end{array}$} & \multirow{3}{*}{ 均 } & \multicolumn{4}{|c|}{ 培 } & \multicolumn{2}{|c|}{ 韹 } & \multicolumn{2}{|c|}{ 日 } & \multicolumn{4}{|c|}{ 数 } \\
\hline & & & & \multicolumn{2}{|c|}{ 第 } & 1 & 日 & \multicolumn{2}{|c|}{ 第 } & 2 & & \multicolumn{2}{|c|}{ 第 } & 3 & 日 \\
\hline & & & & $\begin{array}{l}\text { 登育 } \\
\text { 面䅡 } \\
\end{array}$ & 平均 & $\begin{array}{l}\text { 比襄 } \\
\text { 成長倘 }\end{array}$ & $\begin{array}{l}\text { 成長 } \\
\text { 係数 }\end{array}$ & $\begin{array}{l}\text { 発育 } \\
\text { 西積 }\end{array}$ & 平均 & 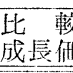 & 成長 & $\begin{array}{l}\text { 発青 } \\
\text { 面積 } \\
\end{array}$ & 平均 & $\begin{array}{l}\text { 比 較 } \\
\text { 成長偳 }\end{array}$ & 成長 \\
\hline 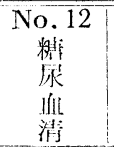 & $\begin{array}{r}410 \\
(10)\end{array}$ & $\begin{array}{l}1.1 \\
1.0 \\
1.0 \\
1.0 \\
1.0\end{array}$ & 1.0 & $\begin{array}{l}18.5 \\
12.8 \\
15.8 \\
17.3 \\
18.4\end{array}$ & 16.6 & 15.6 & 0.61 & $\begin{array}{l}25.2 \\
17.6 \\
18.1 \\
26.2 \\
22.9\end{array}$ & 22.0 & 21.0 & 0.69 & $\begin{array}{l}28.3 \\
20.9 \\
20.1 \\
29.1 \\
24.8\end{array}$ & 24.6 & 23.6 & 0.70 \\
\hline $\begin{array}{c}\text { No. K 12 } \\
\text { 站 } \\
\text { 监 } \\
\text { IfuL } \\
\text { 洁 }\end{array}$ & 110 & $\begin{array}{l}1.1 \\
1.0 \\
1.0 \\
1.0 \\
1.0\end{array}$ & 1.0 & $\begin{array}{l}24.5 \\
22.8 \\
30.0 \\
28.1 \\
27.9\end{array}$ & 26.6 & 25.6 & & $\begin{array}{l}30.8 \\
31.2 \\
33.5 \\
31.6 \\
29.9\end{array}$ & 31.4 & 30.4 & & $\begin{array}{l}33.5 \\
34.2 \\
38.2 \\
35.4 \\
32.5\end{array}$ & 34.8 & 33.8 & \\
\hline
\end{tabular}


第25表 健常組織に家鬼血清添玑した場合(㘼蔵)

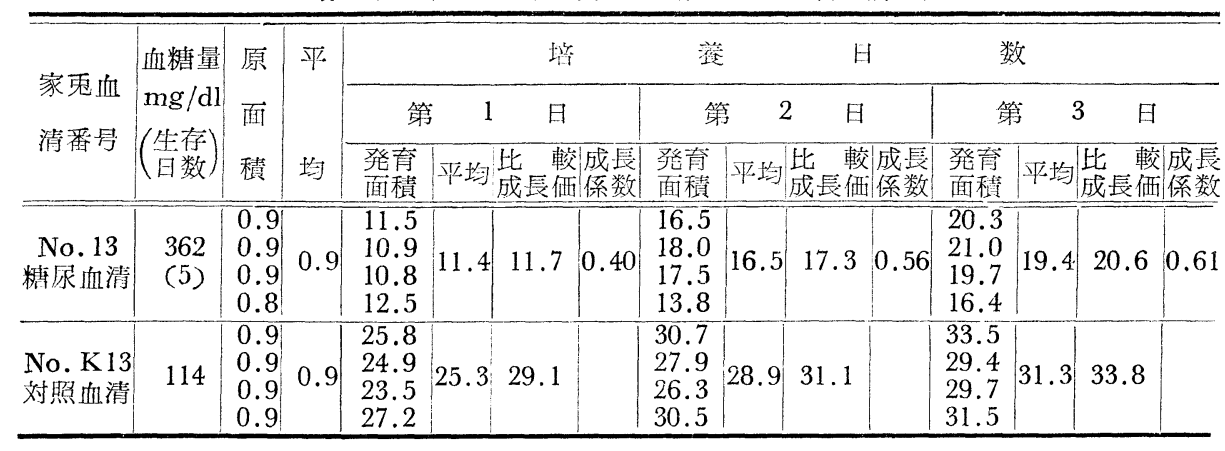

第26表 健常組織飞家鬼血清添加した場合(脾臟)

\begin{tabular}{|c|c|c|c|c|c|c|c|c|c|c|c|c|c|c|c|}
\hline \multirow{3}{*}{ 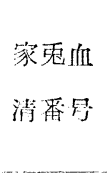 } & \multirow{3}{*}{$\begin{array}{l}\text { 血糖量 } \\
\mathrm{mg} / \mathrm{dl} \\
\left(\frac{\text { 告存 }}{\mathrm{H}}\right)\end{array}$} & \multirow{3}{*}{$\begin{array}{l}\text { 原 } \\
\text { 面 } \\
\text { 箖 }\end{array}$} & \multirow{3}{*}{$\begin{array}{l}\text { 平 } \\
\text { 均 }\end{array}$} & \multicolumn{4}{|c|}{ 培 } & \multicolumn{2}{|c|}{ 邫 } & \multicolumn{2}{|c|}{ 日 } & \multicolumn{2}{|c|}{ 数 } & & \\
\hline & & & & \multicolumn{2}{|c|}{ 第 } & \multicolumn{2}{|l|}{ 日 } & \multicolumn{2}{|c|}{ 第 } & \multicolumn{2}{|l|}{2 日 } & \multicolumn{2}{|c|}{ 第 } & \multicolumn{2}{|c|}{3} \\
\hline & & & & $\begin{array}{l}\text { 热育 } \\
\text { 偭積 }\end{array}$ & 平域 & $\begin{array}{l}\text { 比 較 } \\
\text { 成長伹 }\end{array}$ & $\begin{array}{l}\text { 合㑹長 } \\
\text { i係数 }\end{array}$ & $\begin{array}{l}\text { 発育 } \\
\text { 面稘 }\end{array}$ & 平均 & $\begin{array}{l}\text { 比較 } \\
\text { 成㱐俩 }\end{array}$ & $\begin{array}{l}\text { 成長 } \\
\text { 係数 }\end{array}$ & $\begin{array}{l}\text { 発青 } \\
\text { 面楮䩀 }\end{array}$ & 平均 & $\begin{array}{ll}\text { 比 } & \text { 較 } \\
\text { 战声侀 }\end{array}$ & $\begin{array}{l}\text { 成長 } \\
\text { 係数 }\end{array}$ \\
\hline 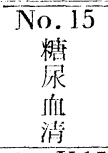 & $\begin{array}{r}312 \\
(10)\end{array}$ & $\begin{array}{l}0.9 \\
0.9 \\
0.9 \\
0.9 \\
0.8 \\
\end{array}$ & 0.9 & $\begin{array}{l}16.3 \\
14.2 \\
14.8 \\
16.3 \\
17.2\end{array}$ & 15.8 & 16.6 & 0.53 & $\begin{array}{l}23.1 \\
19.6 \\
18.2 \\
21.2 \\
23.4\end{array}$ & 21.1 & 22.4 & 0.61 & $\begin{array}{l}24.0 \\
22.3 \\
20.5 \\
23.2 \\
25.1\end{array}$ & 23.0 & 24.6 & 0.56 \\
\hline 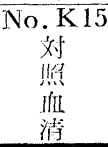 & 134 & $\begin{array}{l}0.9 \\
0.9 \\
0.9 \\
0.9 \\
0.8\end{array}$ & 0.9 & $\begin{array}{l}29.2 \\
34.5 \\
29.5 \\
27.2 \\
26.3\end{array}$ & 29.3 & 31.6 & & $\begin{array}{l}36.5 \\
40.2 \\
35.2 \\
34.3 \\
32.7\end{array}$ & 35.8 & 38.8 & & $\begin{array}{l}40.1 \\
42.7 \\
40.5 \\
39.1 \\
38.3\end{array}$ & 40.1 & 43.6 & \\
\hline
\end{tabular}

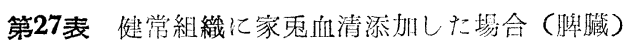

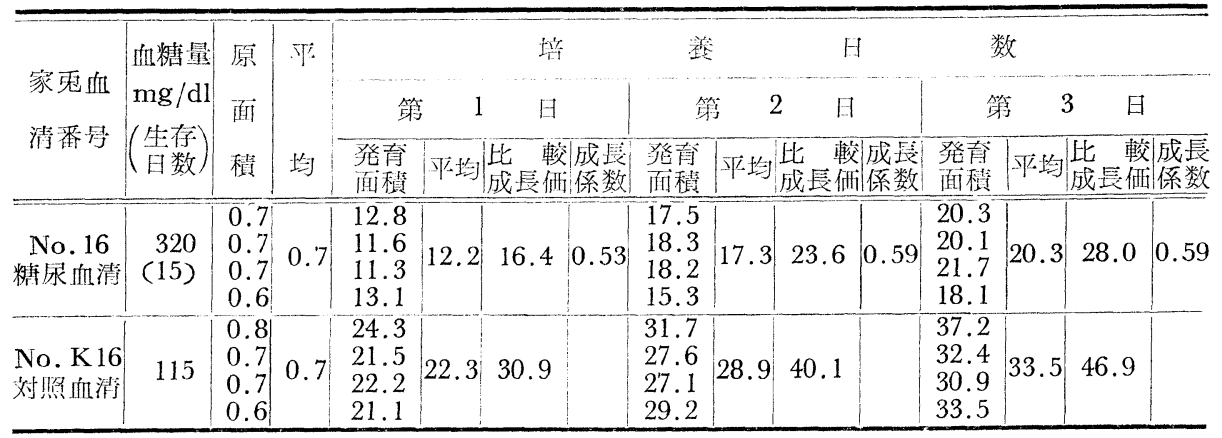

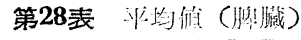

\begin{tabular}{|c|c|c|c|c|}
\hline 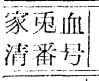 & $\begin{array}{l}\text { Ind糖鳆 } \\
\mathrm{mg} / \mathrm{dl}\end{array}$ & $\begin{array}{r}\text { 塪 } \\
\text { 第 } 1 \text { 日 } \\
\end{array}$ & $\begin{array}{l}\text { 篗 } \mathrm{H} \\
\text { 第 } 2 \mathrm{H}\end{array}$ & $\begin{array}{l}\text { 数 } \\
\text { 第 } 3 \mathrm{H}\end{array}$ \\
\hline 11 & 340 & 0.68 & 0.69 & 0.71 \\
\hline 12 & 410 & 0.61 & 0.69 & 0.70 \\
\hline 13 & 362 & 0.40 & 0.56 & 0.61 \\
\hline 15 & 312 & 0.53 & $0.6 \mathrm{I}$ & 0.56 \\
\hline 16 & 320 & 0.53 & 0.59 & 0.59 \\
\hline 平均 & & 0.55 & 0.63 & 0.63 \\
\hline
\end{tabular}

\section{第 3 節「ア」糖尿家鬼処置血清の組織生育に及ぼす影響}

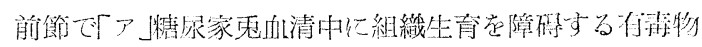

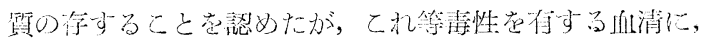
1） $56^{\circ} \mathrm{C} ， 60$ 分加熱による熱非働化，2）シャンベラン L:

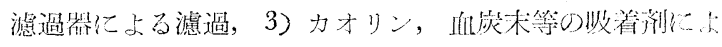

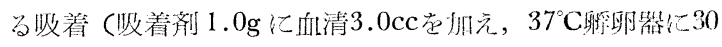

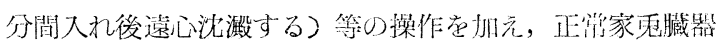

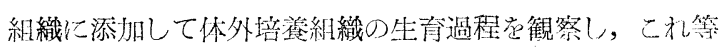


第29表 処置糖尿家鬼血清添加の場合 (骨髄)

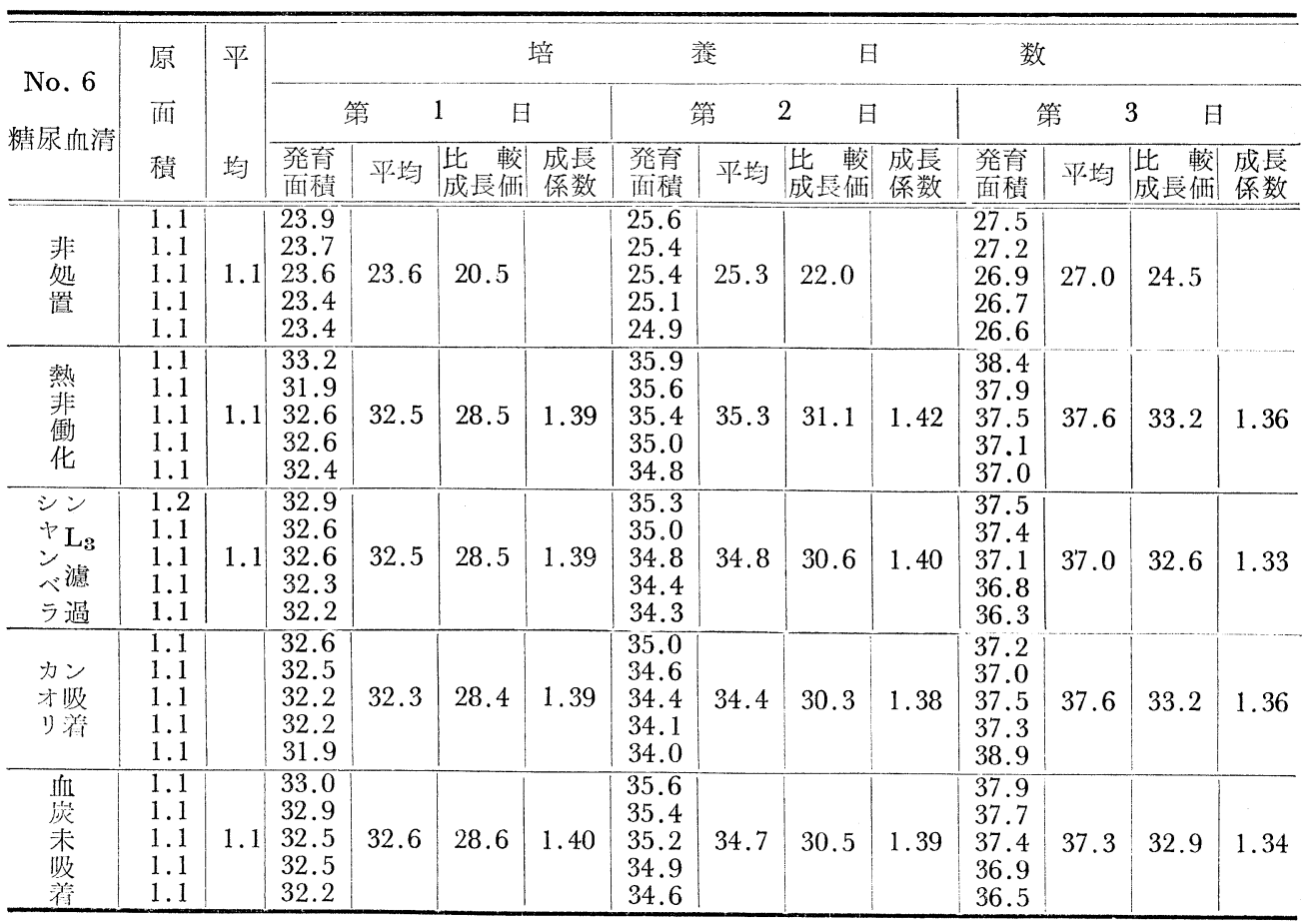

第30表 処置糖尿家鬼血清添加の場合（骨骮倠）

\begin{tabular}{|c|c|c|c|c|c|c|c|c|c|c|c|c|c|c|}
\hline \multirow{3}{*}{$\begin{array}{c}\text { No. } 7 \\
\text { 粒尿的清 }\end{array}$} & \multirow{3}{*}{$\begin{array}{l}\text { 原 } \\
\text { 面 } \\
\text { 積 }\end{array}$} & \multirow{3}{*}{ 平 } & \multicolumn{4}{|c|}{ 培 } & \multicolumn{2}{|c|}{ 養 } & \multicolumn{2}{|c|}{ 日 } & \multicolumn{2}{|c|}{ 数 } & & \\
\hline & & & \multicolumn{2}{|c|}{ 第 } & \multicolumn{2}{|c|}{ 日 } & \multicolumn{2}{|c|}{ 第 } & \multicolumn{2}{|c|}{ 日 } & \multicolumn{2}{|c|}{ 第 } & \multicolumn{2}{|c|}{ 日 } \\
\hline & & & $\begin{array}{l}\text { 発育 } \\
\text { 面皘 }\end{array}$ & 平均 & $\left|\begin{array}{ll}\text { 比 } & \text { 較 } \\
\text { 成長俩 }\end{array}\right|$ & $\begin{array}{l}\text { 成長 } \\
\text { 係数 }\end{array}$ & $\begin{array}{l}\text { 発育 } \\
\text { 面積 }\end{array}$ & 平均 & $\left|\begin{array}{lr}\text { 比 } & \text { 較 } \\
\text { 成長侸i }\end{array}\right|$ & $\begin{array}{l}\text { 成長 } \\
\text { 係数 }\end{array}$ & $\begin{array}{l}\text { 発育 } \\
\text { 面樍 }\end{array}$ & 平均 & $\left|\begin{array}{ll}\text { 比較 } \\
\text { 成長侢 }\end{array}\right|$ & $\begin{array}{l}\text { 成唇 } \\
\text { 係数 }\end{array}$ \\
\hline $\begin{array}{l}\text { 翡 } \\
\text { 処 } \\
\text { 滥 }\end{array}$ & $\begin{array}{l}1.1 \\
1.0 \\
1.0 \\
1.0 \\
1.0\end{array}$ & 1.0 & $\begin{array}{l}22.8 \\
22.8 \\
22.6 \\
22.5 \\
22.4\end{array}$ & 22.6 & 21.6 & & $\begin{array}{l}24.7 \\
24.5 \\
24.4 \\
24.2 \\
24.1\end{array}$ & 24.4 & 23.4 & & $\begin{array}{l}25.6 \\
25.4 \\
25.3 \\
25.0 \\
24.9\end{array}$ & 25.2 & 24.2 & \\
\hline $\begin{array}{l}\text { 驇 } \\
\text { 輩 } \\
\text { 化 }\end{array}$ & $\begin{array}{l}1.0 \\
1.0 \\
1.0 \\
1.0 \\
1.0\end{array}$ & 1.0 & $\begin{array}{l}31.2 \\
31.2 \\
31.0 \\
30.9 \\
30.6\end{array}$ & 31.0 & 30.0 & 1.39 & $\begin{array}{l}34.7 \\
34.4 \\
34.1 \\
33.9 \\
33.9\end{array}$ & 34.2 & 33.2 & 1.42 & $\begin{array}{l}35.9 \\
35.6 \\
35.3 \\
35.1 \\
35.0\end{array}$ & 35.4 & 34.4 & 1.42 \\
\hline $\begin{array}{l}\text { シン } \\
ヤ \mathrm{~L}_{3} \\
\text { ン濾 } \\
\text { ラ過 }\end{array}$ & $\begin{array}{l}1.0 \\
1.0 \\
1.0 \\
1.0 \\
1.0 \\
\end{array}$ & 1.0 & $\begin{array}{l}31.3 \\
31.1 \\
31.0 \\
30.8 \\
30.8 \\
\end{array}$ & 31.0 & 30.0 & 1.39 & $\begin{array}{l}34.8 \\
34.5 \\
34.4 \\
34.1 \\
33.9\end{array}$ & 34.3 & 33.3 & 1.42 & $\begin{array}{l}36.1 \\
35.8 \\
35.5 \\
35.5 \\
35.1\end{array}$ & 35.6 & 34.6 & 1.43 \\
\hline $\begin{array}{l}\text { カン } \\
\text { オ吸 } \\
\text { リ着 }\end{array}$ & $\begin{array}{l}1.1 \\
1.0 \\
1.0 \\
1.0 \\
0.9\end{array}$ & 1.0 & $\begin{array}{l}31.9 \\
31.8 \\
31.5 \\
30.5 \\
30.4\end{array}$ & 31.2 & 30.2 & 1.40 & $\begin{array}{l}34.4 \\
34.1 \\
33.8 \\
33.6 \\
33.5\end{array}$ & 33.9 & 32.9 & 1.40 & $\begin{array}{l}35.4 \\
35.3 \\
35.1 \\
34.8 \\
34.5\end{array}$ & 35.0 & 34.0 & 1.40 \\
\hline 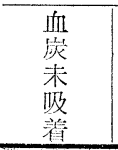 & $\begin{array}{l}1.1 \\
1.0 \\
1.0 \\
1.0 \\
1.0\end{array}$ & 1.0 & $\begin{array}{l}31.4 \\
31.3 \\
31.1 \\
31.0 \\
30.8 \\
\end{array}$ & 31.1 & 30.1 & 1.40 & $\begin{array}{l}34.7 \\
34.6 \\
34.3 \\
34.2 \\
33.2 \\
\end{array}$ & 34.3 & 33.3 & 1.42 & $\begin{array}{l}35.8 \\
35.8 \\
35.6 \\
35.3 \\
34.9\end{array}$ & 35.5 & 34.5 & 1.43 \\
\hline
\end{tabular}




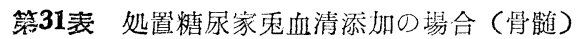

\begin{tabular}{|c|c|c|c|c|c|c|c|c|c|c|c|c|c|c|}
\hline \multirow{3}{*}{$\begin{array}{c}\text { No. } 8 \\
\text { 糖尿血清 }\end{array}$} & \multirow{3}{*}{$\begin{array}{l}\text { 原 } \\
\text { 程i }\end{array}$} & \multirow{3}{*}{ 场 } & \multicolumn{4}{|c|}{ 培 } & \multicolumn{2}{|c|}{ 差 } & \multicolumn{2}{|c|}{ 日 } & \multicolumn{2}{|c|}{ 数 } & & \\
\hline & & & \multicolumn{2}{|c|}{ 第 } & \multicolumn{2}{|c|}{ 日 } & \multicolumn{2}{|c|}{ 第 } & \multicolumn{2}{|c|}{ 日 } & \multicolumn{2}{|c|}{ 第 } & \multicolumn{2}{|c|}{ 日 } \\
\hline & & & $\begin{array}{l}\text { 発青 } \\
\text { 面積 }\end{array}$ & 平均 & $\begin{array}{l}\text { 比 } \\
\text { 成言佼 }\end{array}$ & $\begin{array}{l}\text { 成長 } \\
\text { 係数 }\end{array}$ & $\begin{array}{l}\text { 発育 } \\
\text { 面積 }\end{array}$ & 平均 & $\begin{array}{ll}\text { 比 } & \text { 較 } \\
\text { 成長俩 }\end{array}$ & $\begin{array}{l}\text { 成長 } \\
\text { 係数 }\end{array}$ & $\begin{array}{l}\text { 發育 } \\
\text { 面積 }\end{array}$ & 平均 & $\left|\begin{array}{ll}\text { 比 } & \text { 較 } \\
\text { 成長価 }\end{array}\right|$ & \begin{tabular}{|l} 
成長 \\
係数
\end{tabular} \\
\hline $\begin{array}{l}\text { 非 } \\
\text { 処 } \\
\text { 置 }\end{array}$ & $\begin{array}{l}1.1 \\
1.1 \\
1.1 \\
1.0 \\
1.0\end{array}$ & 1.1 & $\begin{array}{l}23.6 \\
23.6 \\
23.4 \\
23.3 \\
23.1 \\
\end{array}$ & 23.4 & 20.3 & & $\begin{array}{l}25.6 \\
25.6 \\
25.3 \\
25.2 \\
24.9 \\
\end{array}$ & 25.3 & 22.0 & & $\begin{array}{l}28.1 \\
27.8 \\
27.7 \\
27.4 \\
27.2\end{array}$ & 27.6 & 24.1 & \\
\hline $\begin{array}{l}\text { 熱 } \\
\text { 翡 } \\
\text { 働 } \\
\text { 化 }\end{array}$ & $\begin{array}{l}1.1 \\
1.1 \\
1.0 \\
1.0 \\
1.0\end{array}$ & 1.0 & $\begin{array}{l}29.4 \\
29.3 \\
29.3 \\
29.1 \\
28.9\end{array}$ & 29.2 & 28.2 & 1.39 & $\begin{array}{l}32.1 \\
31.9 \\
31.6 \\
31.5 \\
31.4\end{array}$ & 31.7 & 30.7 & 1.39 & $\begin{array}{l}33.8 \\
33.6 \\
33.3 \\
33.2 \\
32.8\end{array}$ & 33.3 & 32.3 & 1.34 \\
\hline $\begin{array}{l}\text { シン } \\
\text { ヤ } \mathrm{L}_{3} \\
\text { シ滤 } \\
\text { ラ渦 }\end{array}$ & $\begin{array}{l}1.1 \\
1.0 \\
1.0 \\
1.0 \\
1.0\end{array}$ & 1.0 & $\begin{array}{l}29.2 \\
39.0 \\
28.9 \\
28.7 \\
28.6 \\
\end{array}$ & 28.9 & 27.9 & 1.37 & $\begin{array}{l}31.6 \\
31.4 \\
31.2 \\
31.1 \\
30.8\end{array}$ & 31.2 & 30.2 & 1.37 & $\begin{array}{l}33.3 \\
32.9 \\
32.7 \\
32.4 \\
32.3\end{array}$ & 32.7 & 31.7 & 1.32 \\
\hline $\begin{array}{l}\text { カン } \\
\text { オ财 } \\
\text { リ着 }\end{array}$ & $\begin{array}{l}1.1 \\
1.0 \\
1.0 \\
1.0 \\
1.0\end{array}$ & 1.0 & $\begin{array}{l}28.8 \\
28.6 \\
28.4 \\
28.3 \\
28.3 \\
\end{array}$ & 28.5 & 27.5 & 1.35 & $\begin{array}{l}30.9 \\
30.8 \\
30.7 \\
30.5 \\
30.2 \\
\end{array}$ & 30.6 & 29.6 & 1.35 & $\begin{array}{l}32.7 \\
32.6 \\
32.4 \\
32.1 \\
31.9 \\
\end{array}$ & 32.3 & 31.3 & 1.30 \\
\hline $\begin{array}{l}\text { 血 } \\
\text { 宸 } \\
\text { 未 } \\
\text { 牢 } \\
\text { 着 }\end{array}$ & $\begin{array}{l}1.0 \\
1.0 \\
1.0 \\
1.0 \\
1.0\end{array}$ & 1.0 & $\begin{array}{l}29.1 \\
28.9 \\
28.7 \\
28.6 \\
28.6 \\
\end{array}$ & 28.8 & 27.8 & 1.37 & $\begin{array}{l}31.8 \\
31.5 \\
31.2 \\
31.0 \\
30.9 \\
\end{array}$ & 31.3 & 30.3 & 1.38 & $\begin{array}{l}33.5 \\
33.2 \\
33.0 \\
32.5 \\
32.4 \\
\end{array}$ & 32.9 & 31.9 & 1.32 \\
\hline
\end{tabular}

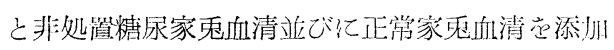
した堤合とを比較検討した。

\section{第 1 項「ア」糖尿家鬼処置血清と非処置 「ア糖尿家鬼血清との関係}

\section{1 愠璡}

垁験成績は表29～31亿示守如く，此等処置糖尿 血清は非処置糖尿血清に比心組織の生育抑制度は 或る程度減弱される。即ち平均すると表 32 亿示す

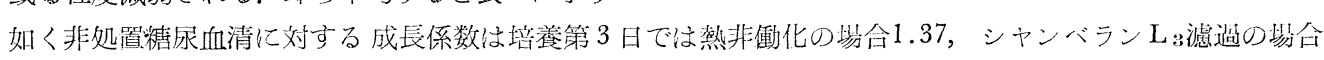
1.36 ，カオリン吸着の場合 1.35 ，血崖末吸着の場合 1.36 ある.

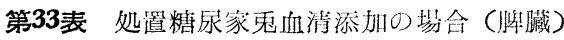

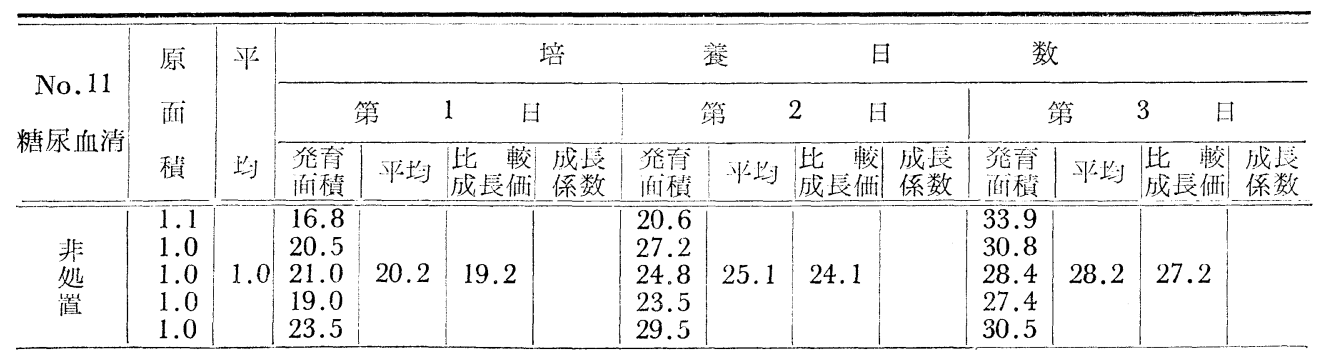

第32表 平均值(骨傕)

\begin{tabular}{|c|c|c|c|}
\hline & 培 & 鉒 & 数 \\
\hline & 第 1 日 & 第 2 日 & 第 3 日 \\
\hline 熱非働化 & 1.39 & 1.38 & 1.37 \\
\hline シャンベランL:滤過 & 1.38 & 1.40 & 1.36 \\
\hline カオりン吸看 & 1.38 & 1.38 & 1.35 \\
\hline 血炭未吸着 & 1.39 & 1.40 & 1.36 \\
\hline
\end{tabular}




\begin{tabular}{|c|c|c|c|c|c|c|c|c|c|c|c|c|c|c|}
\hline $\begin{array}{l}\text { 熱 } \\
\text { 非 } \\
\text { 働 } \\
\text { 化 }\end{array}$ & $\begin{array}{l}1.0 \\
1.0 \\
1.0 \\
1.0 \\
0.9\end{array}$ & 1.0 & $\begin{array}{l}25.8 \\
28.5 \\
23.5 \\
30.0 \\
32.9\end{array}$ & 28.1 & 27.1 & 1.41 & $\begin{array}{l}30.2 \\
34.1 \\
26.7 \\
35.5 \\
36.9\end{array}$ & 32.7 & 31.7 & 1.32 & $\begin{array}{l}38.1 \\
36.3 \\
34.5 \\
42.6 \\
38.3\end{array}$ & 38.0 & 37.0 & 1.36 \\
\hline $\begin{array}{l}\text { シン } \\
+L_{3} \\
\text { ン. } \\
\text { ベ滤 } \\
\text { ラ過 }\end{array}$ & $\begin{array}{l}1.0 \\
1.0 \\
1.0 \\
1.0 \\
0.9\end{array}$ & 1.0 & $\begin{array}{l}24.8 \\
22.8 \\
32.8 \\
24.5 \\
25.7\end{array}$ & 26.1 & 25.1 & 1.32 & $\begin{array}{l}32.8 \\
28.1 \\
38.1 \\
28.8 \\
29.1\end{array}$ & 31.4 & 30.4 & 1.26 & $\begin{array}{l}40.1 \\
30.7 \\
43.1 \\
30.8 \\
32.5\end{array}$ & 35.4 & 34.4 & 1.26 \\
\hline $\begin{array}{l}\text { カン } \\
\text { 㼔 } \\
\text { リ着 }\end{array}$ & $\begin{array}{l}1.1 \\
1.0 \\
1.0 \\
1.0 \\
1.0\end{array}$ & 1.0 & $\begin{array}{l}28.5 \\
24.2 \\
27.0 \\
24.8 \\
29.5\end{array}$ & 26.8 & 25.8 & 1.34 & $\begin{array}{l}32.5 \\
32.0 \\
30.2 \\
29.2 \\
34.0\end{array}$ & 31.6 & 30.6 & 1.27 & $\begin{array}{l}34.0 \\
34.2 \\
32.5 \\
32.9 \\
37.0\end{array}$ & 34.1 & 33.1 & 1.22 \\
\hline 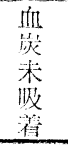 & $\begin{array}{l}1.0 \\
1.0 \\
1.0 \\
1.0 \\
1.0 \\
\end{array}$ & 1.0 & $\begin{array}{l}25.2 \\
32.0 \\
30.2 \\
28.2 \\
22.8 \\
\end{array}$ & 27.7 & 26.7 & 1.39 & $\begin{array}{l}30.0 \\
39.5 \\
37.9 \\
29.1 \\
27.8 \\
\end{array}$ & 32.9 & 31.9 & 1.32 & $\begin{array}{l}35.5 \\
45.0 \\
43.5 \\
33.1 \\
29.3\end{array}$ & 37.4 & 36.4 & 1.34 \\
\hline
\end{tabular}

第34表 処置精尿家鬼血清添加の場合(脾藏)

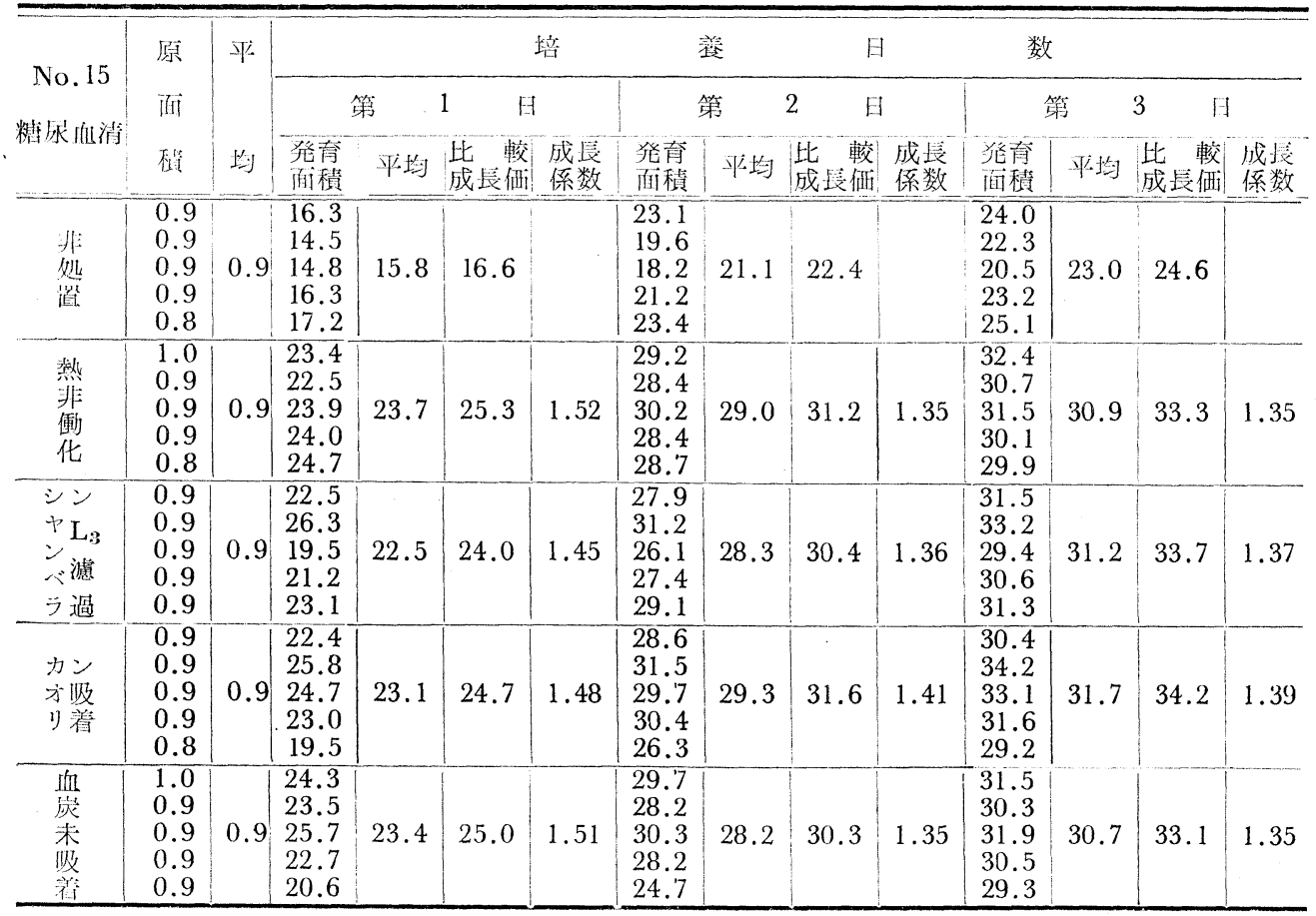

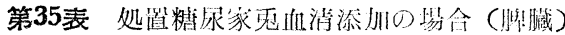

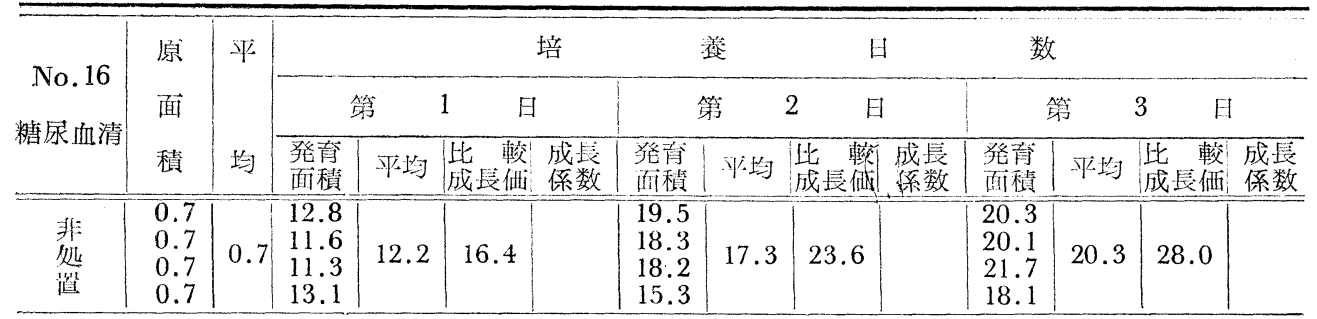




\begin{tabular}{|c|c|c|c|c|c|c|c|c|c|c|c|c|c|c|}
\hline $\begin{array}{l}\text { 熱 } \\
\text { 翡 } \\
\text { 化 } \\
\end{array}$ & $\begin{array}{l}0.8 \\
0.7 \\
0.7 \\
0.7\end{array}$ & 0.7 & $\begin{array}{l}18.3 \\
19.4 \\
17.8 \\
19.3\end{array}$ & 18.7 & 25.7 & 1.57 & $\begin{array}{l}26.2 \\
26.3 \\
24.3 \\
24.5\end{array}$ & 25.4 & 35.3 & 1.50 & $\begin{array}{l}30.3 \\
29.9 \\
28.8 \\
27.2\end{array}$ & 29.1 & 40.6 & 1.45 \\
\hline 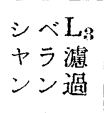 & $\begin{array}{l}0.8 \\
0.7 \\
0.7 \\
0.6\end{array}$ & 0.7 & $\begin{array}{l}20.4 \\
17.1 \\
19.2 \\
16.9\end{array}$ & 18.4 & 25.3 & 1.54 & $\begin{array}{l}26.3 \\
26.6 \\
25.1 \\
21.9\end{array}$ & 25.0 & 34.7 & 1.47 & $\begin{array}{l}28.2 \\
29.2 \\
29.3 \\
26.8\end{array}$ & 28.4 & 39.6 & 1.41 \\
\hline $\begin{array}{l}\text { カン } \\
\text { 才吸 } \\
\text { リ着 }\end{array}$ & $\begin{array}{l}0.7 \\
0.7 \\
0.7 \\
0.7\end{array}$ & 0.7 & $\begin{array}{l}17.8 \\
16.5 \\
20.1 \\
19.5\end{array}$ & 18.5 & 25.4 & 1.55 & $\begin{array}{l}26.9 \\
22.5 \\
28.0 \\
26.1\end{array}$ & 25.9 & 36.0 & 1.58 & $\begin{array}{l}29.4 \\
26.1 \\
29.5 \\
28.3\end{array}$ & 28.3 & 39.4 & 1.41 \\
\hline $\begin{array}{l}\text { 血未 } \\
\text { 败 } \\
\text { 炭着 }\end{array}$ & $\begin{array}{l}0.7 \\
0.7 \\
0.7 \\
0.6\end{array}$ & 0.7 & $\begin{array}{l}16.3 \\
17.3 \\
22.1 \\
20.2\end{array}$ & 19.0 & 26.1 & 1.59 & $\begin{array}{l}22.5 \\
22.9 \\
27.4 \\
27.3\end{array}$ & 25.0 & 34.7 & 1.47 & $\begin{array}{l}23.6 \\
25.7 \\
31.4 \\
32.5\end{array}$ & 28.3 & 39.4 & 1.41 \\
\hline
\end{tabular}

2 脾臓

奏験成縝は表33〜35亿示す如くで情娟道の場合と 䁬々同様の傾问定示し，平均9ると表36亿示多如

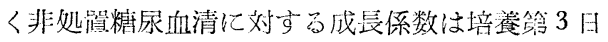

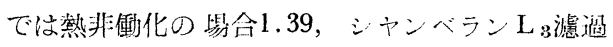
の昜合 1.35 , カオリン吸着の昜合 1.34 , 血炭某败 視の場合 1.33 であり，糖㽷家鬼血清の組織生育㕝 障碍する或る種有毒物質心熱に弱く, 非濾過性, 被吸着性であるものと考えられる。
管36表 壮均佰（脾藏）

\begin{tabular}{|c|c|c|c|}
\hline & 垛 & 港 & 数 \\
\hline & 第 1 日 & 第 2 回 & 第 311 \\
\hline 热非徵化 & 1.50 & 1.39 & 1.39 \\
\hline シャンベラン $\mathrm{L}_{3}$ 滤過 & 1.44 & 1.36 & 1.35 \\
\hline カオリン吸着 & 1.46 & 1.42 & 1.34 \\
\hline 血炭未财矔 & 1.47 & 1.35 & 1.33 \\
\hline
\end{tabular}

\section{第 2 項「ア糖尿家鬼処置血清と非処置正常家鬼血清との関係}

1 算璡

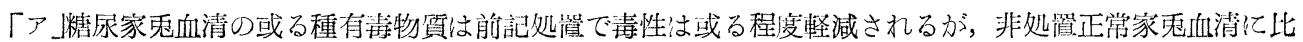

第37表 処置糖尿家鬼血清添加の埸合(肯䯕) (対照はNo.K6血清)

\begin{tabular}{|c|c|c|c|}
\hline \multirow{2}{*}{ No. 6 糖尿血清 } & 培 & 養 & 数 \\
\hline & 第 1 日 & 第 2 日 & 第 3 日 \\
\hline 熱非働化 & 0.85 & 0.85 & 0.87 \\
\hline シナンベラン $\mathrm{L}_{3}$ 溜過 & 0.85 & 0.81 & 0.86 \\
\hline カオリン吸消 & 0.85 & 0.83 & 0.87 \\
\hline 血炭末吸着 & 0.86 & 0.84 & 0.87 \\
\hline
\end{tabular}

第39表 処置糖尿家鬼血清添加の場合（骨能道） (対照はNo.K8血清)

\begin{tabular}{|c|c|c|c|}
\hline \multirow{2}{*}{ No. 8 精泉血势 } & 培 & 镱 & 数 \\
\hline & 第 1 日 & 第 2 日 & 第 $3 \mathrm{H}$ \\
\hline 熱非働化 & 0.79 & 0.80 & 0.80 \\
\hline シャンベラン $\mathrm{L}_{3}$ 滤過 & 0.78 & 0.79 & 0.79 \\
\hline カオリン收着 & 0.77 & 0.77 & 0.78 \\
\hline 血炭未吸着 & 0.78 & 0.79 & 0.79 \\
\hline
\end{tabular}

第38表 処置精尿家鬼血清添加の場合（学漰進） (対照はNo. K7 血嘴)

\begin{tabular}{|c|c|c|c|}
\hline \multirow{2}{*}{ No. 7 糛尿血清 } & 培 & 䔶 & 数 \\
\hline & 第 1 日 & 第 2 日 & 第 $3 \mathrm{EI}$ \\
\hline 熱非働化 & 0.87 & 0.89 & 0.88 \\
\hline シャンベラン $\mathrm{L}_{3}$ 滤過 & 0.87 & 0.89 & 0.88 \\
\hline カホリン财着 & 0.88 & 0.88 & 0.87 \\
\hline 血炭未吸着 & 0.88 & 0.89 & 0.88 \\
\hline
\end{tabular}

第40表 平均値 (骨髄)

\begin{tabular}{|c|c|c|c|}
\hline & 培 & 篒 日 & 数 \\
\hline & 第 1 日 & 第 2 日 & 第 3 H \\
\hline 熱非働化 & 0.83 & 0.85 & 0.85 \\
\hline シャンベラン $\mathrm{L}_{\mathbf{3}}$ 㴧過 & 0.83 & 0.83 & 0.84 \\
\hline カオリン财着 & 0.83 & 0.83 & 0.84 \\
\hline 血炭未吸着 & 0.83 & 0.84 & 0.85 \\
\hline
\end{tabular}


634

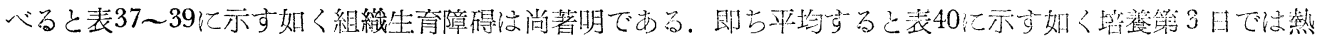
非働化の場合 0.85 ，シャンベラン $\mathrm{L}_{3}$ 滤過の場合 0.84 ，カオリン叫着の場命 0.84 ，血竾末吸着の埸合 0.85 で ある.

\section{2 搼蔵}

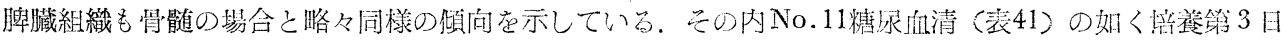

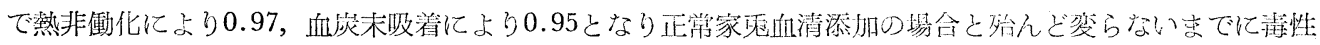
の軽減されたものもあつた。平均すると墙養第 3 日では表44亿示す如く熱非慟化の場合 0.86 , シャンベラン

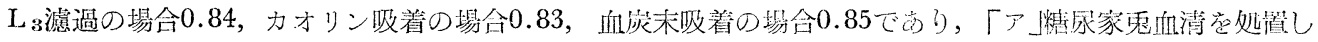

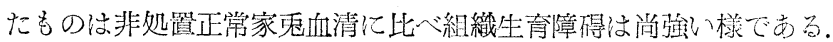

第41表 処㯰糖尿家鬼血清添加の埸合（脾臟） （対照はNo.K11血消）

\begin{tabular}{|c|c|c|c|}
\hline \multirow{2}{*}{ No. 11 糛尿血清 } & 培 & 養 & 数 \\
\hline & 第 1 日 & 第 2 日 & 第 3 日 \\
\hline 熱非動化 & 0.96 & 0.91 & 0.97 \\
\hline シャンベラン $\mathrm{L}_{3}$ 瀷過 & 0.89 & 0.87 & 0.90 \\
\hline カォリン吸神 & 0.91 & 0.88 & 0.86 \\
\hline 血岑未吸着 & 0.95 & 0.91 & 0.95 \\
\hline
\end{tabular}

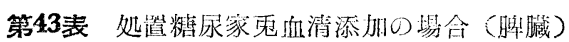
(刘照は No.K16血清)

\begin{tabular}{|c|c|c|c|}
\hline \multirow{2}{*}{ No.16糖尿血简 } & 䏴 & 䇥 日 & 数 \\
\hline & 第 1 日 & 第 2 日 & 第 3 日 \\
\hline 熱非働化 & 0.83 & 0.88 & 0.87 \\
\hline シャンベラン La滤過 & 0.82 & 0.87 & 0.84 \\
\hline カオリン级稚 & 0.82 & 0.90 & 0.84 \\
\hline 血荻未吸得 & 0.80 & 0.87 & 0.84 \\
\hline
\end{tabular}

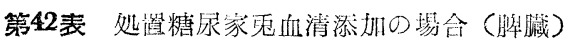
(刘照はNo. K15血清)

\begin{tabular}{|c|c|c|c|}
\hline \multirow{2}{*}{ No. 15梼尿血清 } & 培 & 筷 日 & 数 \\
\hline & 第 1 日 & 第 2 日 & 第 3 日 \\
\hline 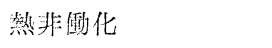 & 0.80 & 0.80 & 0.76 \\
\hline シャンベラン $\mathrm{L}_{3}$ 淿過 & 0.76 & 0.78 & 0.77 \\
\hline カメリン昅着 & 0.78 & 0.82 & 0.78 \\
\hline 䇽炭未吸福 & 0.76 & 0.78 & 0.76 \\
\hline
\end{tabular}

第44表 平均推(脾臟)

\begin{tabular}{|c|c|c|c|}
\hline & 堷 & 得 日 & 数 \\
\hline & 第 1 日 & 第 2 日 & 第 3 日 \\
\hline 熱非働化 & 0.86 & 0.86 & 0.86 \\
\hline シャンベラン $\mathrm{L}_{3}$ 濳過 & 0.82 & 0.84 & 0.84 \\
\hline カオリン政着 & 0.84 & 0.87 & 0.83 \\
\hline 血荻未吸滰 & 0.84 & 0.85 & 0.8 .5 \\
\hline
\end{tabular}

\section{第 3 項 正常家鬼処置血淸と非処置正常家鬼血淸との関係}

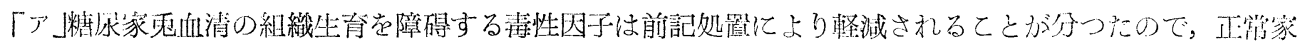

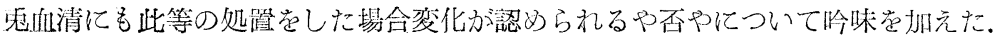

1 骨髄

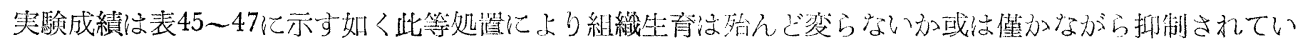

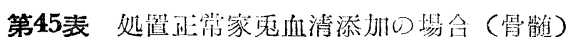

\begin{tabular}{|c|c|c|c|c|c|c|c|c|c|c|c|c|c|c|}
\hline \multirow{3}{*}{$\begin{array}{l}\text { No. K6 } \\
\text { 対照血清 }\end{array}$} & \multirow{3}{*}{$\begin{array}{l}\text { 原 } \\
\text { 画 } \\
\text { 積 }\end{array}$} & \multirow{3}{*}{ 平 } & \multicolumn{5}{|c|}{ 堦 } & 染 & \multicolumn{2}{|c|}{ 日 } & \multicolumn{2}{|c|}{ 数 } & & \\
\hline & & & \multicolumn{2}{|c|}{ 第 } & \multicolumn{2}{|c|}{$1 \quad 11$} & \multicolumn{2}{|c|}{ 第 } & \multicolumn{2}{|c|}{$H$} & \multicolumn{2}{|c|}{ 第 } & 日 & \\
\hline & & & $\begin{array}{l}\text { 発育 } \\
\text { 南门䅆 }\end{array}$ & 平均 & \begin{tabular}{|l|} 
比較 \\
成烄価
\end{tabular} & $\begin{array}{l}\text { 成長 } \\
\text { 係数 }\end{array}$ & $\begin{array}{l}\text { 発青 } \\
\text { 面積 }\end{array}$ & 平均 & $\mid \begin{array}{ll}\text { 比 } & \text { 較 } \\
\text { 成玨価 }\end{array}$ & $\begin{array}{l}\text { 成舆 } \\
\text { 係数 }\end{array}$ & $\begin{array}{l}\text { 発育 } \\
\text { 面䅡 } \\
\end{array}$ & 平均 & $\begin{array}{l}\text { 比較 } \\
\text { 成長価 }\end{array}$ & $\begin{array}{l}\text { 成長 } \\
\text { 係数 }\end{array}$ \\
\hline $\begin{array}{l}\text { 非 } \\
\text { 处 } \\
\text { 喍 }\end{array}$ & $\begin{array}{l}1.1 \\
1.1 \\
1.1 \\
1.1 \\
1.1\end{array}$ & 1.1 & $\begin{array}{l}38.3 \\
38.0 \\
37.8 \\
37.5 \\
37.4 \\
\end{array}$ & 37.8 & 33.4 & & $\begin{array}{l}41.8 \\
41.6 \\
41.1 \\
40.9 \\
40.9\end{array}$ & 41.2 & 36.5 & & $\begin{array}{l}44.6 \\
44.1 \\
43.9 \\
43.3 \\
43.0 \\
\end{array}$ & 43.8 & 37.9 & \\
\hline
\end{tabular}




\begin{tabular}{|c|c|c|c|c|c|c|c|c|c|c|c|c|c|c|}
\hline $\begin{array}{l}\text { 熱 } \\
\text { 䧳 } \\
\text { 化 }\end{array}$ & $\begin{array}{l}1.2 \\
1.1 \\
1.1 \\
1.1 \\
1.1\end{array}$ & 1.1 & $\begin{array}{l}38.5 \\
38.3 \\
37.9 \\
37.8 \\
37.5\end{array}$ & 38.0 & 33.5 & 1.00 & $\begin{array}{l}42.0 \\
41.8 \\
41.5 \\
41.0 \\
40.6\end{array}$ & 41.4 & 36.6 & 1.00 & $\begin{array}{l}45.0 \\
44.8 \\
44.1 \\
43.8 \\
43.2\end{array}$ & 43.2 & 38.3 & 1.01 \\
\hline $\begin{array}{l}\text { シン } \\
\text { ヤ } \mathrm{L}_{3} \\
\text { 之. } \\
\text { ヘ濾 } \\
\text { ラ過 }\end{array}$ & $\begin{array}{l}1.1 \\
1.1 \\
1.1 \\
1.1 \\
1.1\end{array}$ & 1.1 & $\begin{array}{l}38.0 \\
37.9 \\
37.6 \\
37.4 \\
37.1\end{array}$ & 37.6 & 33.2 & 0.99 & $\begin{array}{l}41.8 \\
41.3 \\
41.1 \\
40.7 \\
40.5\end{array}$ & 41.1 & 36.4 & 1.00 & $\begin{array}{l}44.2 \\
44.0 \\
43.5 \\
43.1 \\
42.6\end{array}$ & 43.5 & 38.5 & 1.01 \\
\hline $\begin{array}{l}\text { カン } \\
\text { オ吸 } \\
\text { リ着 }\end{array}$ & $\begin{array}{l}1.2 \\
1.1 \\
1.1 \\
1.1 \\
1.1\end{array}$ & 1.1 & $\begin{array}{l}38.2 \\
37.9 \\
37.7 \\
37.4 \\
37.2\end{array}$ & 37.7 & 33.3 & 1.00 & $\begin{array}{l}41.7 \\
41.2 \\
40.8 \\
40.5 \\
40.4\end{array}$ & 40.9 & 36.2 & 0.99 & $\begin{array}{l}43.9 \\
43.7 \\
43.3 \\
42.9 \\
42.4 \\
\end{array}$ & 43.2 & 38.3 & 1.01 \\
\hline $\begin{array}{l}\text { 血 } \\
\text { 笑 } \\
\text { 先 } \\
\text { 吊 } \\
\text { 着 }\end{array}$ & $\begin{array}{l}1.1 \\
1.1 \\
1.1 \\
1.1 \\
1.1\end{array}$ & 1.1 & $\begin{array}{l}38.2 \\
38.1 \\
37.8 \\
37.3 \\
37.1\end{array}$ & 37.7 & 33.3 & 1.00 & $\begin{array}{l}41.8 \\
41.3 \\
41.1 \\
40.8 \\
40.4\end{array}$ & 41.1 & 36.4 & 1.00 & $\begin{array}{l}44.2 \\
43.6 \\
43.3 \\
42.8 \\
42.5 \\
\end{array}$ & 43.3 & 38.4 & 1.01 \\
\hline
\end{tabular}

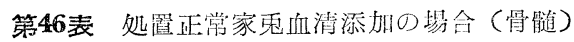

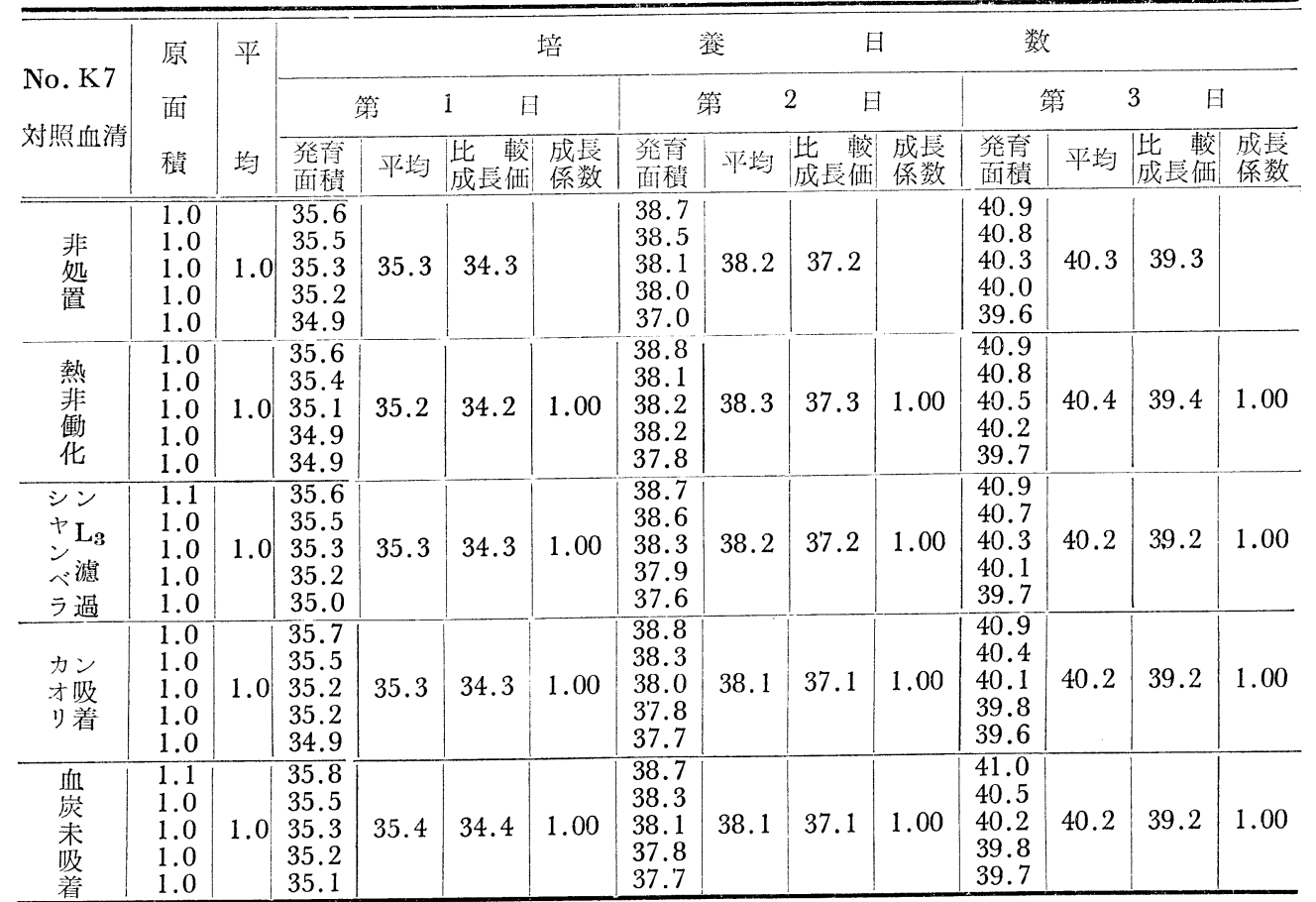

第47表 処置正常家鬼血清添加の場合 (骨夥)

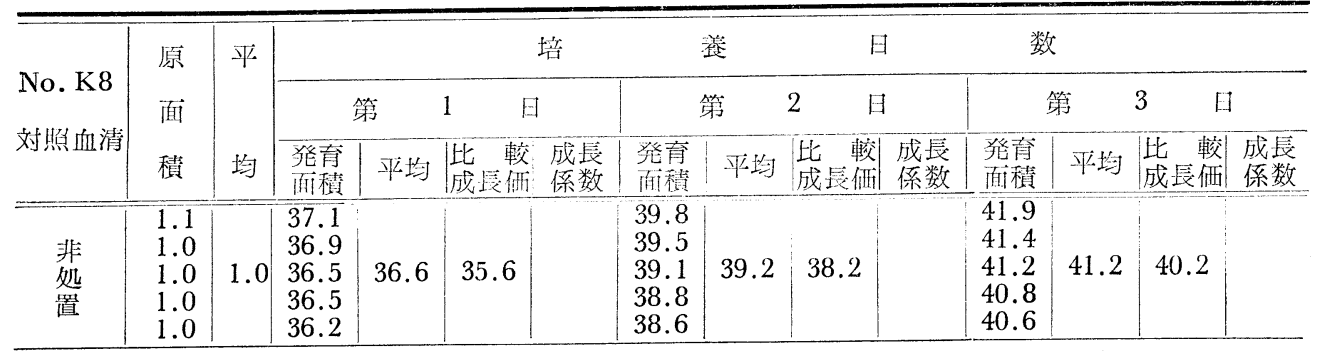




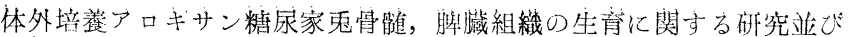
に組織の生育に及ばすアロキサン䊰尿家鬼血清の影樂 (増田, 奥村)

\begin{tabular}{|c|c|c|c|c|c|c|c|c|c|c|c|c|c|c|}
\hline $\begin{array}{l}\text { 熱 } \\
\text { 侐 } \\
\text { 化 } \\
\text { 化 }\end{array}$ & $\begin{array}{l}1.1 \\
1.1 \\
1.1 \\
1.0 \\
1.0\end{array}$ & 1.1 & $\begin{array}{l}37.8 \\
37.7 \\
37.4 \\
37.2 \\
36.9 \\
\end{array}$ & 37.4 & 33.0 & 0.93 & $\begin{array}{l}40.7 \\
40.6 \\
40.3 \\
40.0 \\
39.5 \\
\end{array}$ & 40.2 & 35.5 & 0.93 & $\begin{array}{l}43.7 \\
43.5 \\
43.1 \\
42.7 \\
42.2\end{array}$ & 43.0 & 38.1 & 0.95 \\
\hline 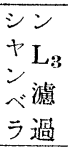 & $\begin{array}{l}1.1 \\
1.0 \\
1.0 \\
1.0 \\
1.0\end{array}$ & 1.0 & $\begin{array}{l}37.0 \\
37.0 \\
36.8 \\
36.5 \\
36.2\end{array}$ & 36.7 & 35.7 & 1.00 & $\begin{array}{l}39.7 \\
39.6 \\
39.2 \\
39.0 \\
38.6\end{array}$ & 39.2 & 38.2 & 1.00 & $\begin{array}{l}41.8 \\
41.5 \\
41.1 \\
40.9 \\
40.4\end{array}$ & 41.1 & 40.1 & 1.00 \\
\hline $\begin{array}{l}\text { カン } \\
\text { オ吸 } \\
\text { リ着 }\end{array}$ & $\begin{array}{l}1.1 \\
1.1 \\
1.1 \\
1.0 \\
1.0\end{array}$ & 1.1 & $\begin{array}{l}37.7 \\
37.5 \\
37.4 \\
37.2 \\
36.9 \\
\end{array}$ & 37.3 & 33.0 & 0.93 & $\begin{array}{l}40.6 \\
40.5 \\
40.2 \\
39.8 \\
39.4\end{array}$ & 40.1 & 35.5 & 0.93 & $\begin{array}{l}43.0 \\
42.8 \\
42.5 \\
42.1 \\
41.7\end{array}$ & 42.4 & 37.5 & 0.93 \\
\hline $\begin{array}{l}\text { 血 } \\
\text { 炭 } \\
\text { 未 } \\
\text { 吸 } \\
\text { 着 }\end{array}$ & $\begin{array}{l}1.0 \\
1.0 \\
1.0 \\
1.0 \\
1.0 \\
\end{array}$ & 1.0 & $\begin{array}{l}37.0 \\
36.7 \\
36.4 \\
36.3 \\
36.2 \\
\end{array}$ & 36.5 & 35.5 & 1.00 & $\begin{array}{l}39.9 \\
39.4 \\
39.1 \\
38.9 \\
38.7\end{array}$ & 39.2 & 38.2 & 1.00 & $\begin{array}{l}41.6 \\
41.5 \\
41.2 \\
40.8 \\
40.3\end{array}$ & 41.1 & 40.1 & 1.00 \\
\hline
\end{tabular}

る。本均すると表48亿示す如く培養節 3 日では非 処虽正常血清に対する成長係数は，熱非働化の埸 合 0.99 , シャンベラン $\mathrm{L}_{3}$ 濾過の場合 1.00 , 力ォ リン忣着の場合 0.98 ，血炭末吸着の埸合 1.00 であ 3.

2 脾臟

脾藏組織では表49〜51亿示す如く此等好监血清 の組織生育に及ばす影響は殆んど隹め難く, 平均
第48表 平均值（骨髄）

\begin{tabular}{|c|c|c|c|}
\hline & 培 & 榇 & 数 \\
\hline & 第 1 日 & 第 2 日 & 第 3 日 \\
\hline 熱非働化 & 0.98 & 0.98 & 0.99 \\
\hline シャンベラン $\mathrm{L}_{3}$ 鰓過 & 1.00 & 1.00 & 1.00 \\
\hline カオリン财着 & 0.98 & 0.97 & 0.98 \\
\hline 血资未吸着 & 1.00 & 1.00 & 1.00 \\
\hline
\end{tabular}

第49表 処置正常家鬼血清添加の場合(脾藏)

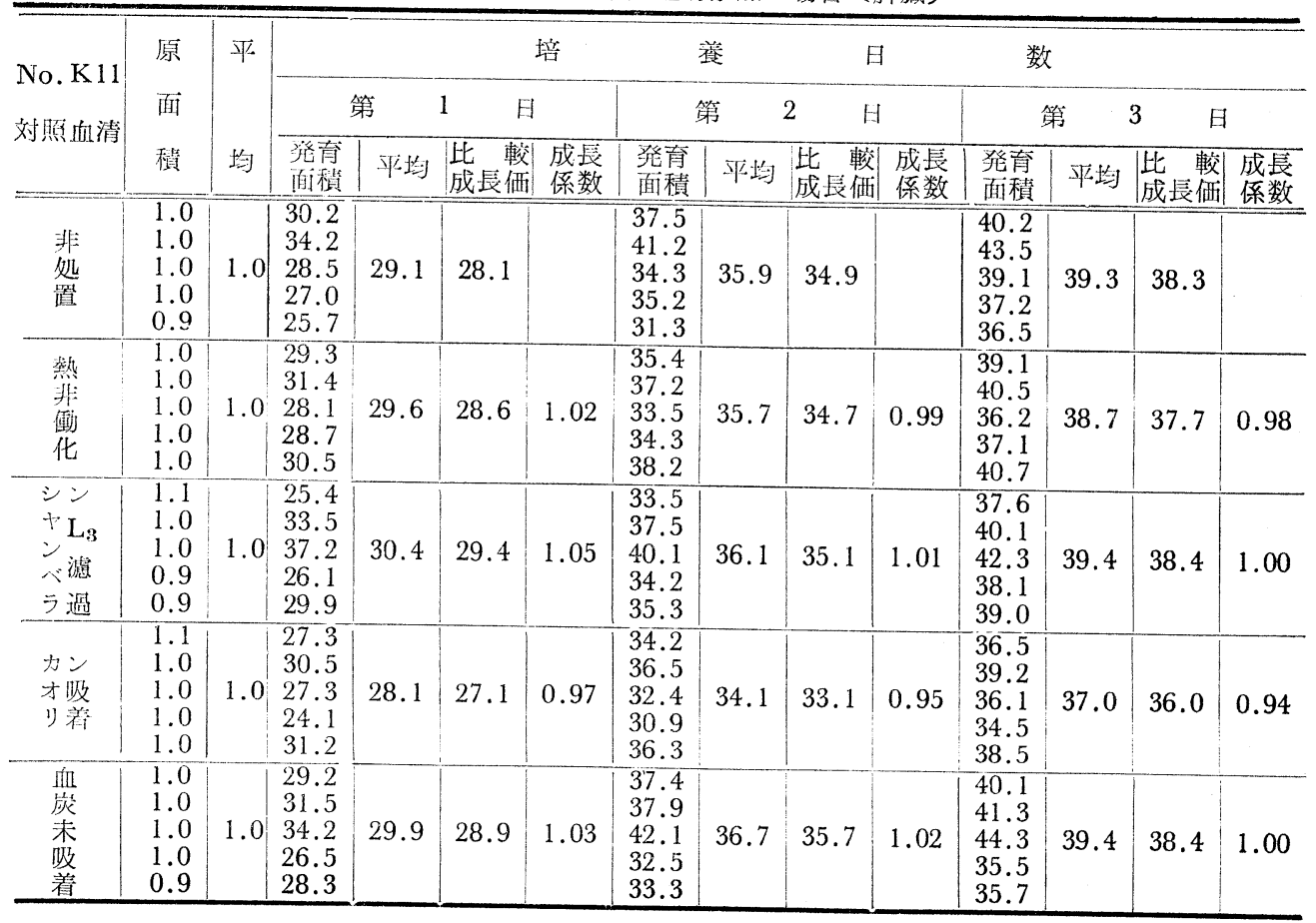


第50表 処置正常家鬼血清添加の場合（脾臟）

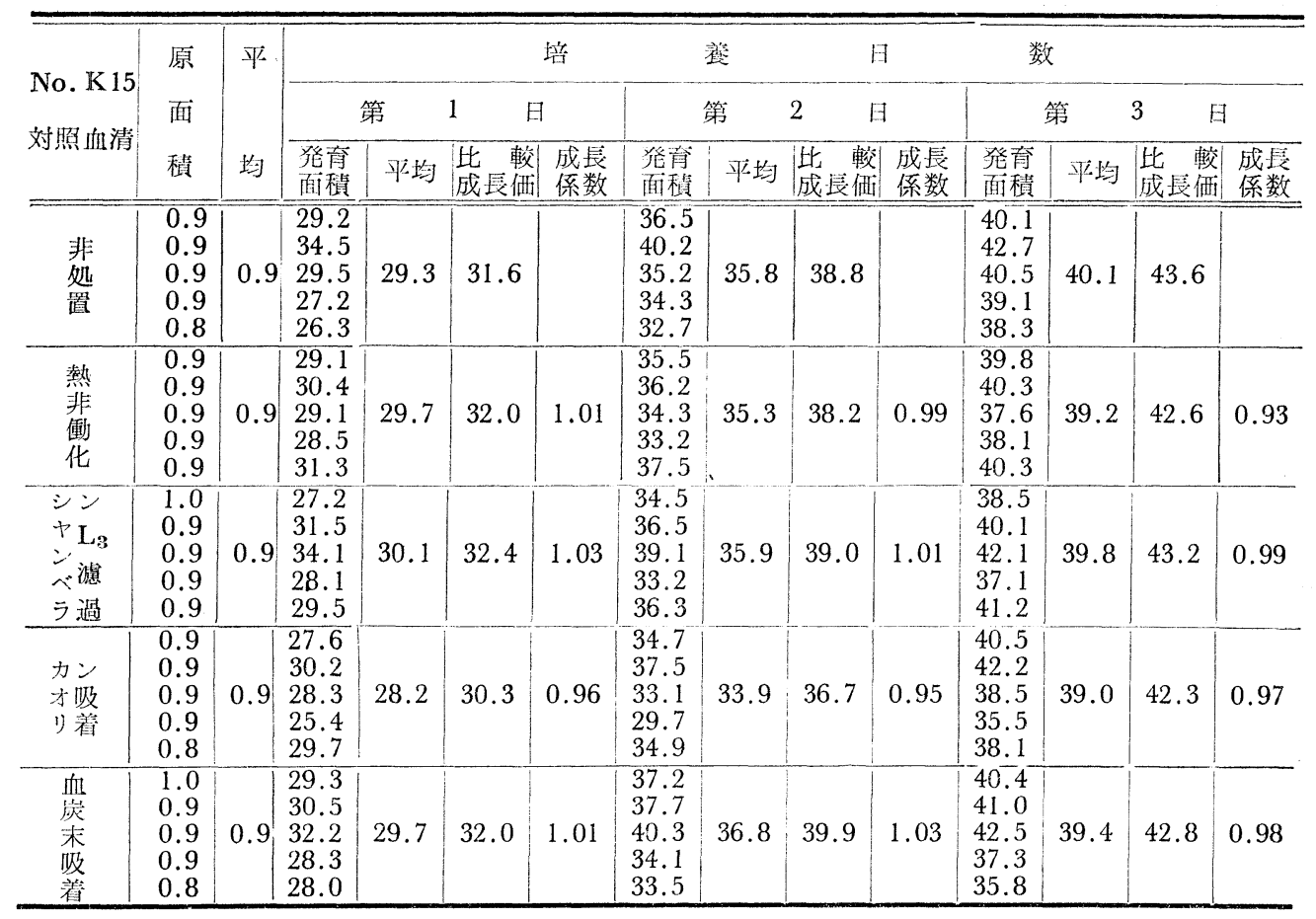

第51表 処置正常家鬼血潜添加の場合 (脾藏)

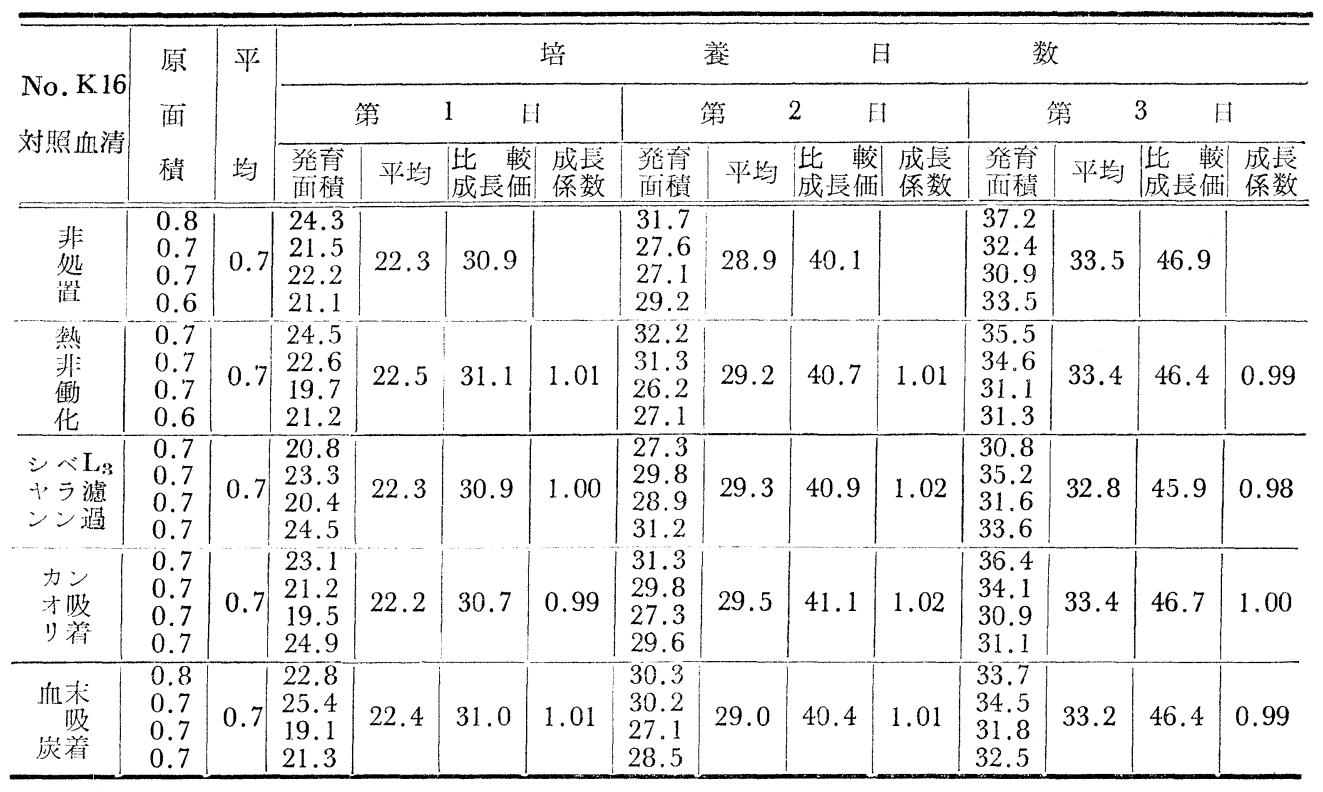


第52表 平均值 (脾臟)

\begin{tabular}{|c|c|c|c|}
\hline & \multicolumn{2}{|c|}{ 培 䍰 } & 数 \\
\hline & 第 1 日 & 第 2 日 & 第 3 日 \\
\hline 熱非働化 & 1.01 & 1.00 & 0.97 \\
\hline シャンベラン $\mathrm{L}_{3}$ 滤過 & 1.02 & 1.01 & 0.99 \\
\hline カオリン财着 & 0.97 & 0.99 & 0.97 \\
\hline 血炭末财着 & 1.02 & 1.02 & 0.99 \\
\hline
\end{tabular}

すると表52亿示ず如く培養第 3 日では非处置正常 血清江対する成長係数は，熱非働化の場合 0.97 ， シヤンベラン L 9 濾過の場合 0.99 , カオリン吸着 の塨合 0.97 ，血炭末吸着の場合 0.99 であり，正常 血清に組蟣生㻆を抑制する因子はないものと思 われる。

\section{第 4 節 糖濃度と骨髓及び脾䁍組織生育} との関伱

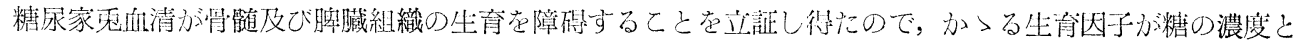
如何なる関係他あるふる検索した。

第 1 項 骨䯈

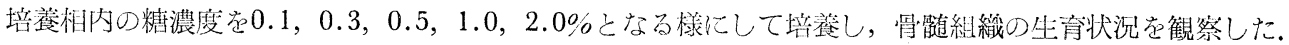

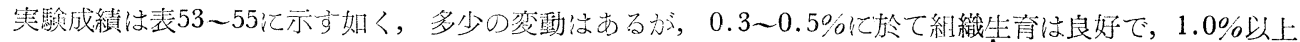
になると障碍されている.

括均すると表 56 亿示す如く，培養第 3 日では対照飞刘する成長係数は，0.1\%で1.06，0.3\%で1.19，0.5 \%で1.13，1.0\%で0.86，2.0\%で0.6となり，0.3\%に於て組織生育は最宅良好で，0.5\%，0.1\%，1.0\%， $2.0 \%$ 順序に弱くなる。

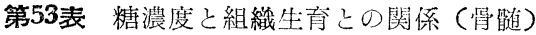

\begin{tabular}{|c|c|c|c|c|c|c|c|c|c|c|c|c|c|c|}
\hline \multirow{3}{*}{$\begin{array}{c}\text { 鋯濃度 } \\
(\%)\end{array}$} & \multirow{3}{*}{$\begin{array}{l}\text { 原 } \\
\text { 面 } \\
\text { 積 }\end{array}$} & \multirow{3}{*}{$\begin{array}{l}\text { 平 } \\
\text { 均 }\end{array}$} & \multicolumn{4}{|c|}{ 培 } & \multicolumn{2}{|c|}{ 羕 } & \multicolumn{2}{|c|}{ 日 } & \multicolumn{2}{|c|}{ 数 } & & \\
\hline & & & \multicolumn{2}{|c|}{ 第 } & \multicolumn{2}{|c|}{ 日 } & \multicolumn{2}{|c|}{ 第 } & \multicolumn{2}{|c|}{ 日 } & \multicolumn{2}{|c|}{ 第 } & \multicolumn{2}{|c|}{ 日 } \\
\hline & & & $\begin{array}{l}\text { 登育 } \\
\text { 面積 }\end{array}$ & 平均 & $\begin{array}{l}\text { 比 較 } \\
\text { 成脣価 }\end{array}$ & $\begin{array}{l}\text { 成泰 } \\
\text { 係数 }\end{array}$ & $\begin{array}{l}\text { 発育 } \\
\text { 面䅡 }\end{array}$ & 平均 & $\begin{array}{l}\text { 比較 } \\
\text { 成長価 }\end{array}$ & $\begin{array}{l}\text { 成脣 } \\
\text { 係数 }\end{array}$ & $\begin{array}{l}\text { 発育 } \\
\text { 面積 }\end{array}$ & 平均 & $\mid \begin{array}{ll}\mid \begin{array}{ll}\text { 比 } \\
\text { 較 } \\
\text { 成長価 }\end{array}\end{array}$ & $\begin{array}{l}\text { 成長 } \\
\text { 係数 }\end{array}$ \\
\hline 対 照 & $\begin{array}{l}1.2 \\
1.1 \\
1.1 \\
1.1\end{array}$ & 1.1 & $\begin{array}{l}30.6 \\
30.9 \\
29.2 \\
28.7\end{array}$ & 29.9 & 26.2 & & $\begin{array}{l}40.1 \\
39.1 \\
38.6 \\
37.5\end{array}$ & 38.8 & 34.3 & & $\begin{array}{l}44.5 \\
43.6 \\
42.0 \\
39.7\end{array}$ & 42.5 & 37.6 & \\
\hline 0.1 & $\begin{array}{l}1.2 \\
1.1 \\
1.1 \\
1.1 \\
\end{array}$ & 1.1 & $\begin{array}{l}33.9 \\
32.4 \\
31.2 \\
30.2 \\
\end{array}$ & 31.9 & 28.0 & 1.07 & $\begin{array}{l}42.1 \\
40.0 \\
37.5 \\
36.1\end{array}$ & 38.9 & 34.4 & 1.00 & $\begin{array}{l}45.6 \\
42.5 \\
40.4 \\
38.7\end{array}$ & 41.8 & 37.0 & 0.98 \\
\hline 0.3 & $\begin{array}{l}1.1 \\
1.1 \\
1.1 \\
1.0\end{array}$ & 1.1 & $\begin{array}{l}39.2 \\
37.9 \\
35.8 \\
33.9\end{array}$ & 36.7 & 32.4 & 1.24 & $\begin{array}{l}48.4 \\
46.3 \\
43.9 \\
42.5\end{array}$ & 45.3 & 40.2 & 1.17 & $\begin{array}{l}53.9 \\
51.1 \\
48.4 \\
47.1\end{array}$ & 50.1 & 44.5 & 1.18 \\
\hline 0.5 & $\begin{array}{l}1.3 \\
1.2 \\
1.1 \\
1.1\end{array}$ & 1.2 & $\begin{array}{l}40.8 \\
39.0 \\
37.0 \\
34.9 \\
\end{array}$ & 37.9 & 30.6 & 1.17 & $\begin{array}{l}50.2 \\
48.2 \\
45.2 \\
43.7\end{array}$ & 46.8 & 38.0 & 1.11 & $\begin{array}{l}55.9 \\
53.2 \\
50.1 \\
48.1\end{array}$ & 51.8 & 42.2 & 1.12 \\
\hline 1.0 & $\begin{array}{l}1.2 \\
1.1 \\
1.1 \\
1.0\end{array}$ & 1.1 & $\begin{array}{l}31.0 \\
30.0 \\
28.6 \\
27.6\end{array}$ & 29.3 & 25.6 & 0.98 & $\begin{array}{l}38.7 \\
36.8 \\
35.1 \\
33.8\end{array}$ & 36.1 & 31.8 & 0.92 & $\begin{array}{l}41.8 \\
39.6 \\
37.7 \\
36.5\end{array}$ & 38.9 & 34.4 & 0.91 \\
\hline 2.0 & $\begin{array}{l}1.1 \\
1.1 \\
1.1 \\
1.0\end{array}$ & 1.1 & $\begin{array}{l}17.0 \\
15.9 \\
14.8 \\
14.0\end{array}$ & 15.4 & 13.0 & 0.50 & $\begin{array}{l}22.0 \\
21.1 \\
20.1 \\
19.1\end{array}$ & 20.6 & 17.7 & 0.51 & $\begin{array}{l}23.5 \\
22.9 \\
21.7 \\
20.4\end{array}$ & 22.1 & 19.1 & 0.51 \\
\hline
\end{tabular}


第54表 精濃度と組織生奇との関係（骨輔）

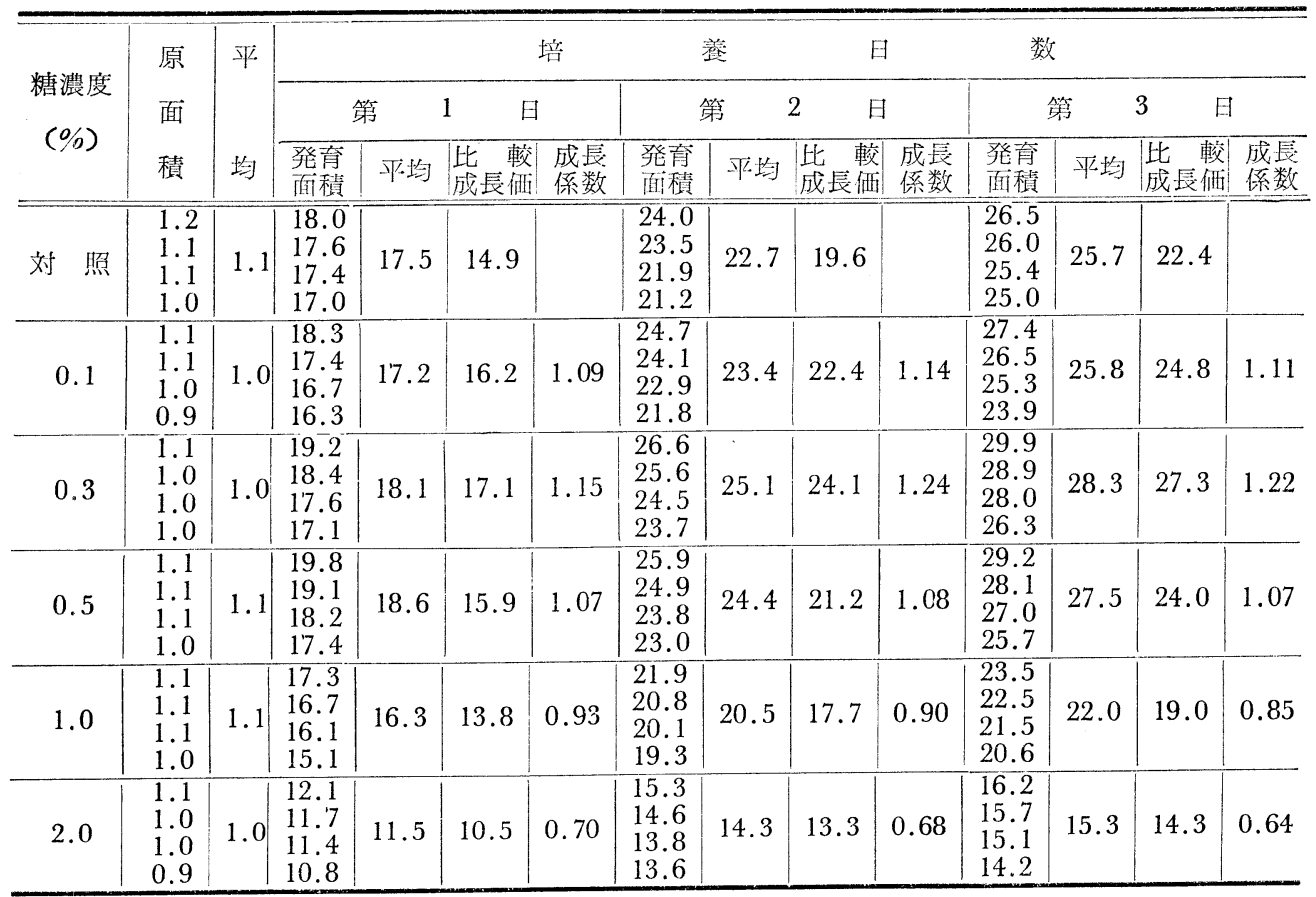

第55表 糖濃度と組織生育との関係(骨䯣)

\begin{tabular}{|c|c|c|c|c|c|c|c|c|c|c|c|c|c|c|}
\hline \multirow{3}{*}{$\begin{array}{c}\text { 糖濃度 } \\
(\%)\end{array}$} & \multirow{3}{*}{$\begin{array}{l}\text { 原 } \\
\text { 面 } \\
\text { 積 }\end{array}$} & \multirow{3}{*}{$\begin{array}{l}\text { 平 } \\
\text { 均 }\end{array}$} & \multicolumn{4}{|c|}{ 培 } & \multicolumn{2}{|c|}{ 養 } & \multicolumn{2}{|c|}{ 日 } & \multicolumn{2}{|c|}{ 数 } & & \\
\hline & & & \multicolumn{2}{|c|}{ 第 } & \multicolumn{2}{|c|}{ 日 } & \multicolumn{2}{|c|}{ 第 } & \multicolumn{2}{|c|}{2 日 } & \multicolumn{2}{|c|}{ 第 } & \multicolumn{2}{|c|}{ 日 } \\
\hline & & & $\begin{array}{l}\text { 發育 } \\
\text { 面積 }\end{array}$ & 平均 & $\begin{array}{l}\text { 比潋 } \\
\text { 成長価 }\end{array}$ & $\begin{array}{l}\text { 成婜 } \\
\text { 係数 }\end{array}$ & $\begin{array}{l}\text { 発青 } \\
\text { 面桡 }\end{array}$ & 平均 & $\begin{array}{l}\text { 比較 } \\
\text { 成長価 }\end{array}$ & $\begin{array}{l}\text { 成長 } \\
\text { 係数 }\end{array}$ & $\begin{array}{l}\text { 発育 } \\
\text { 面積 }\end{array}$ & 平均 & $\mid \begin{array}{ll}\text { 比 } & \text { 較 } \\
\text { 成長価 }\end{array}$ & $\begin{array}{l}\text { 成長 } \\
\text { 係数 }\end{array}$ \\
\hline 対 照 & $\begin{array}{l}1.4 \\
1.3 \\
1.3 \\
1.3\end{array}$ & 1.3 & $\begin{array}{l}28.6 \\
27.9 \\
28.2 \\
27.5\end{array}$ & 28.1 & 20.6 & & $\begin{array}{l}38.5 \\
38.1 \\
38.1 \\
37.6\end{array}$ & 38.1 & 28.3 & & $\begin{array}{l}44.6 \\
43.5 \\
44.0 \\
43.0\end{array}$ & 43.8 & 32.7 & \\
\hline 0.1 & $\begin{array}{l}1.4 \\
1.3 \\
1.3 \\
1.2\end{array}$ & 1.3 & $\begin{array}{l}34.0 \\
33.1 \\
30.9 \\
29.5\end{array}$ & 31.9 & 23.5 & 1.14 & $\begin{array}{l}44.2 \\
42.6 \\
41.3 \\
39.5\end{array}$ & 41.9 & 31.2 & 1.10 & $\begin{array}{l}50.6 \\
48.8 \\
46.8 \\
44.2\end{array}$ & 47.6 & 35.6 & 1.09 \\
\hline 0.3 & $\begin{array}{l}1.3 \\
1.2 \\
1.2 \\
1.2\end{array}$ & 1.2 & $\begin{array}{l}36.3 \\
34.8 \\
33.3 \\
31.6\end{array}$ & 34.0 & 27.3 & 1.33 & $\begin{array}{l}47.1 \\
44.8 \\
42.6 \\
41.5\end{array}$ & 44.0 & 35.7 & 1.26 & $\begin{array}{l}54.1 \\
51.9 \\
49.6 \\
46.8\end{array}$ & 50.6 & 41.2 & 1.16 \\
\hline 0.5 & $\begin{array}{l}1.3 \\
1.3 \\
1.3 \\
1.3\end{array}$ & 1.3 & $\begin{array}{l}41.2 \\
39.5 \\
37.7 \\
36.4\end{array}$ & 38.7 & 28.8 & 1.40 & $\begin{array}{l}53.1 \\
51.3 \\
49.7 \\
47.1\end{array}$ & 50.3 & 37.7 & 1.33 & $\begin{array}{l}59.5 \\
57.6 \\
55.3 \\
52.8\end{array}$ & 56.3 & 42.3 & 1.19 \\
\hline 1.0 & $\begin{array}{l}1.4 \\
1.3 \\
1.3 \\
1.3\end{array}$ & 1.3 & $\begin{array}{l}26.9 \\
26.0 \\
25.0 \\
23.7 \\
\end{array}$ & 25.4 & 18.5 & 0.90 & $\begin{array}{l}35.1 \\
34.0 \\
32.8 \\
31.3\end{array}$ & 33.3 & 24.6 & 0.87 & $\begin{array}{l}38.9 \\
37.4 \\
35.8 \\
33.9\end{array}$ & 36.5 & 27.1 & 0.83 \\
\hline 2.0 & $\begin{array}{l}1.3 \\
1.2 \\
1.2 \\
1.2\end{array}$ & 1.2 & $\begin{array}{l}18.4 \\
17.6 \\
16.6 \\
16.3\end{array}$ & 17.2 & 13.3 & 0.65 & $\begin{array}{l}23.7 \\
22.8 \\
21.9 \\
20.8\end{array}$ & 22.3 & 17.6 & 0.62 & $\begin{array}{l}24.9 \\
23.8 \\
22.7 \\
21.8\end{array}$ & 23.3 & 18.4 & 0.56 \\
\hline
\end{tabular}


第56表 平均值(骨璡)

\begin{tabular}{|c|c|c|c|}
\hline 糖濃度 & 培 & 食 & 数 \\
\hline$(\%)$ & 第 1 日 & 第 2 日 & 第 3 日 \\
\hline 0.1 & 1.10 & 1.08 & 1.06 \\
\hline 0.3 & 1.24 & 1.21 & 1.19 \\
\hline 0.5 & 1.21 & 1.17 & 1.13 \\
\hline 1.0 & 0.94 & 0.90 & 0.86 \\
\hline 2.0 & 0.62 & 0.60 & 0.60 \\
\hline
\end{tabular}

第 2 項 脾

脾藏に於ても骨娟道と略々同様の成績を示し，表57〜 59亿示す如く $1.0 \%$ 以上で組織生育は著明に抑制される。

平均すると表60亿示す如く培意第 3 日では対照に対する成長係数 は, $0.1 \%$ で1.03，0.3\%で $1.20,0.5 \%$ で1.10, $1.0 \%$ で $0.71,2.0$ \%で0.61で0.3\%亿於て組織生育は最も良好であり，0.5\%，0.1\%， $1.0 \%, 2.0 \%$ の順儿弱くなる。

第57表 糖濃度と組織生育との関係（脾藏）

\begin{tabular}{|c|c|c|c|c|c|c|c|c|c|c|c|c|c|c|}
\hline \multirow{3}{*}{$\begin{array}{c}\text { 糖濃度 } \\
(\%)\end{array}$} & \multirow{3}{*}{$\begin{array}{l}\text { 原 } \\
\text { 面 } \\
\text { 積 }\end{array}$} & \multirow{3}{*}{ 平 } & \multicolumn{4}{|c|}{ 培 } & \multicolumn{2}{|c|}{ 養 } & \multicolumn{2}{|c|}{ 日 } & \multicolumn{2}{|c|}{ 数 } & & \\
\hline & & & \multicolumn{2}{|c|}{ 第 } & \multicolumn{2}{|l|}{ 日 } & \multicolumn{2}{|c|}{ 第 } & \multicolumn{2}{|c|}{2} & \multicolumn{2}{|c|}{ 第 } & \multicolumn{2}{|c|}{ 日 } \\
\hline & & & $\begin{array}{l}\text { 発育 } \\
\text { 面積 }\end{array}$ & 平均 & $\left|\begin{array}{ll}\text { 比 } & \text { 較 } \\
\text { 成長価 }\end{array}\right|$ & $\begin{array}{l}\text { 成辰 } \\
\text { 係数 }\end{array}$ & $\begin{array}{l}\text { 登育 } \\
\text { 面積 }\end{array}$ & 平均 & $\mid \begin{array}{ll}\text { 比 } & \text { 較 } \\
\text { 成長俩 }\end{array}$ & $\begin{array}{l}\text { 成長 } \\
\text { 係数 }\end{array}$ & \begin{tabular}{l|} 
発青 \\
面積
\end{tabular} & 平均 & $\left|\begin{array}{ll}\text { 比 } & \text { 較 } \\
\text { 成長俩 }\end{array}\right|$ & $\begin{array}{l}\text { 成長 } \\
\text { 係数 }\end{array}$ \\
\hline 対 照 & $\begin{array}{l}1.1 \\
1.1 \\
1.1 \\
1.1\end{array}$ & 1.1 & $\begin{array}{l}21.8 \\
24.4 \\
23.8 \\
24.2\end{array}$ & 23.6 & 20.5 & & $\begin{array}{l}27.2 \\
29.3 \\
32.1 \\
27.1\end{array}$ & 28.9 & 25.3 & & $\begin{array}{l}30.3 \\
33.5 \\
34.7 \\
30.2\end{array}$ & 32.2 & 28.3 & \\
\hline 0.1 & $\begin{array}{l}1.2 \\
1.1 \\
1.1 \\
1.0\end{array}$ & 1.1 & $\begin{array}{l}24.9 \\
22.5 \\
25.9 \\
26.5 \\
\end{array}$ & 25.0 & 22.6 & 1.10 & $\begin{array}{l}29.3 \\
28.2 \\
28.6 \\
29.4 \\
\end{array}$ & 28.9 & 25.3 & 1.00 & $\begin{array}{l}32.8 \\
31.5 \\
31.0 \\
30.5\end{array}$ & 31.5 & 27.6 & 0.98 \\
\hline 0.3 & $\begin{array}{l}1.2 \\
1.1 \\
1.1 \\
1.1 \\
1\end{array}$ & 1.1 & $\begin{array}{l}29.5 \\
30.4 \\
27.5 \\
29.3 \\
34.5\end{array}$ & 29.2 & 25.5 & 1.24 & $\begin{array}{l}32.5 \\
36.5 \\
31.8 \\
35.2 \\
\end{array}$ & 33.9 & 29.8 & 1.18 & $\begin{array}{l}40.3 \\
41.0 \\
32.7 \\
37.1\end{array}$ & 37.8 & 33.4 & 1.18 \\
\hline 0.5 & $\begin{array}{l}1.1 \\
1.1 \\
1.1 \\
1.0\end{array}$ & 1.1 & $\begin{array}{l}34.3 \\
27.7 \\
28.3 \\
26.1\end{array}$ & 29.1 & 25.4 & 1.24 & $\begin{array}{l}27.8 \\
30.1 \\
33.9 \\
32.5\end{array}$ & 31.3 & 27.5 & 1.09 & $\begin{array}{l}31.5 \\
31.4 \\
36.7 \\
35.7\end{array}$ & 33.8 & 29.7 & 1.05 \\
\hline 1.0 & $\begin{array}{l}1.1 \\
1.1 \\
1.1 \\
1.1\end{array}$ & 1.1 & $\begin{array}{l}19.3 \\
11.8 \\
13.9 \\
17.8\end{array}$ & 15.7 & 13.3 & 0.65 & $\begin{array}{l}22.3 \\
18.5 \\
20.2 \\
19.6\end{array}$ & 20.2 & 17.4 & 0.69 & $\begin{array}{l}23.5 \\
20.2 \\
22.9 \\
21.2\end{array}$ & 22.0 & 19.0 & 0.67 \\
\hline 2.0 & $\begin{array}{l}1.1 \\
1.1 \\
1.1 \\
1.0\end{array}$ & 1.1 & $\begin{array}{r}8.7 \\
11.7 \\
10.4 \\
9.1 \\
\end{array}$ & 10.0 & 8.1 & 0.39 & $\begin{array}{l}11.8 \\
16.2 \\
15.8 \\
13.7\end{array}$ & 14.4 & 12.1 & 0.48 & $\begin{array}{l}14.8 \\
18.9 \\
18.7 \\
14.8\end{array}$ & 16.8 & 14.3 & 0.51 \\
\hline
\end{tabular}

第58表 糖濃度と組織生青この関係(脾灆)

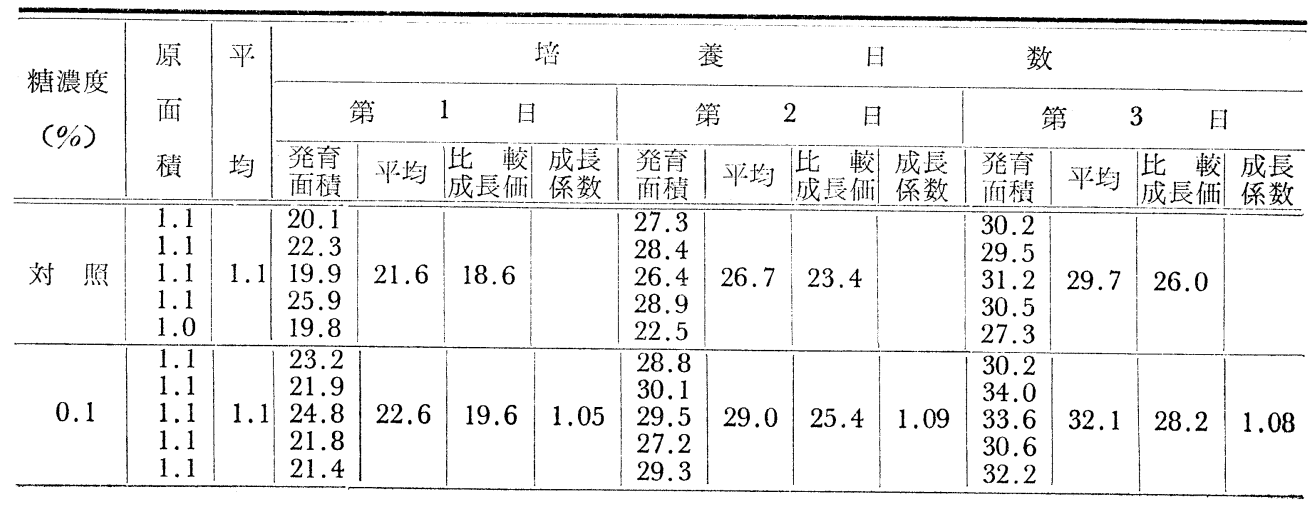




\begin{tabular}{|c|c|c|c|c|c|c|c|c|c|c|c|c|c|c|}
\hline 0.3 & $\begin{array}{l}1.2 \\
1.1 \\
1.1 \\
1.1 \\
1.0\end{array}$ & 1.1 & $\begin{array}{l}24.8 \\
30.5 \\
28.3 \\
22.9 \\
30.4 \\
\end{array}$ & 27.4 & 23.9 & 1.28 & $\begin{array}{l}28.3 \\
36.4 \\
30.7 \\
29.3 \\
38.3\end{array}$ & 32.6 & 28.6 & 1.22 & $\begin{array}{l}31.2 \\
40.2 \\
37.3 \\
30.8 \\
42.2\end{array}$ & 36.0 & 31.7 & 1.22 \\
\hline 0.5 & $\begin{array}{l}1.1 \\
1.1 \\
1.1 \\
1.1 \\
1.0\end{array}$ & 1.1 & $\begin{array}{l}31.4 \\
28.5 \\
21.2 \\
27.8 \\
31.8 \\
\end{array}$ & 28.1 & 24.5 & 1.32 & $\begin{array}{l}33.3 \\
32.1 \\
27.1 \\
30.5 \\
37.2\end{array}$ & 32.0 & 28.1 & 1.20 & $\begin{array}{l}35.2 \\
34.9 \\
30.1 \\
32.3 \\
41.5\end{array}$ & 34.7 & 30.5 & 1.15 \\
\hline 1.0 & $\begin{array}{l}1.2 \\
1.1 \\
1.1 \\
1.1 \\
1.0\end{array}$ & 1.1 & $\begin{array}{l}15.5 \\
19.4 \\
15.8 \\
13.9 \\
10.1 \\
\end{array}$ & 14.9 & 12.5 & 0.67 & $\begin{array}{l}21.3 \\
24.5 \\
22.8 \\
17.8 \\
20.4 \\
\end{array}$ & 21.4 & 18.5 & 0.79 & $\begin{array}{l}24.5 \\
27.0 \\
25.3 \\
20.6 \\
22.3\end{array}$ & 23.9 & 20.7 & 0.80 \\
\hline 2.0 & $\begin{array}{l}1.2 \\
1.1 \\
1.1 \\
1.1 \\
1.0\end{array}$ & 1.1 & $\begin{array}{l}14.0 \\
14.1 \\
13.6 \\
17.1 \\
11.7\end{array}$ & 14.1 & 11.8 & 0.63 & $\begin{array}{l}15.6 \\
19.9 \\
16.4 \\
24.2 \\
18.1\end{array}$ & 18.8 & 16.1 & 0.69 & $\begin{array}{l}17.3 \\
22.5 \\
19.5 \\
26.1 \\
20.4 \\
\end{array}$ & 21.2 & 18.3 & 0.70 \\
\hline
\end{tabular}

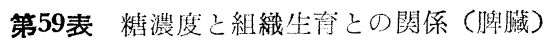

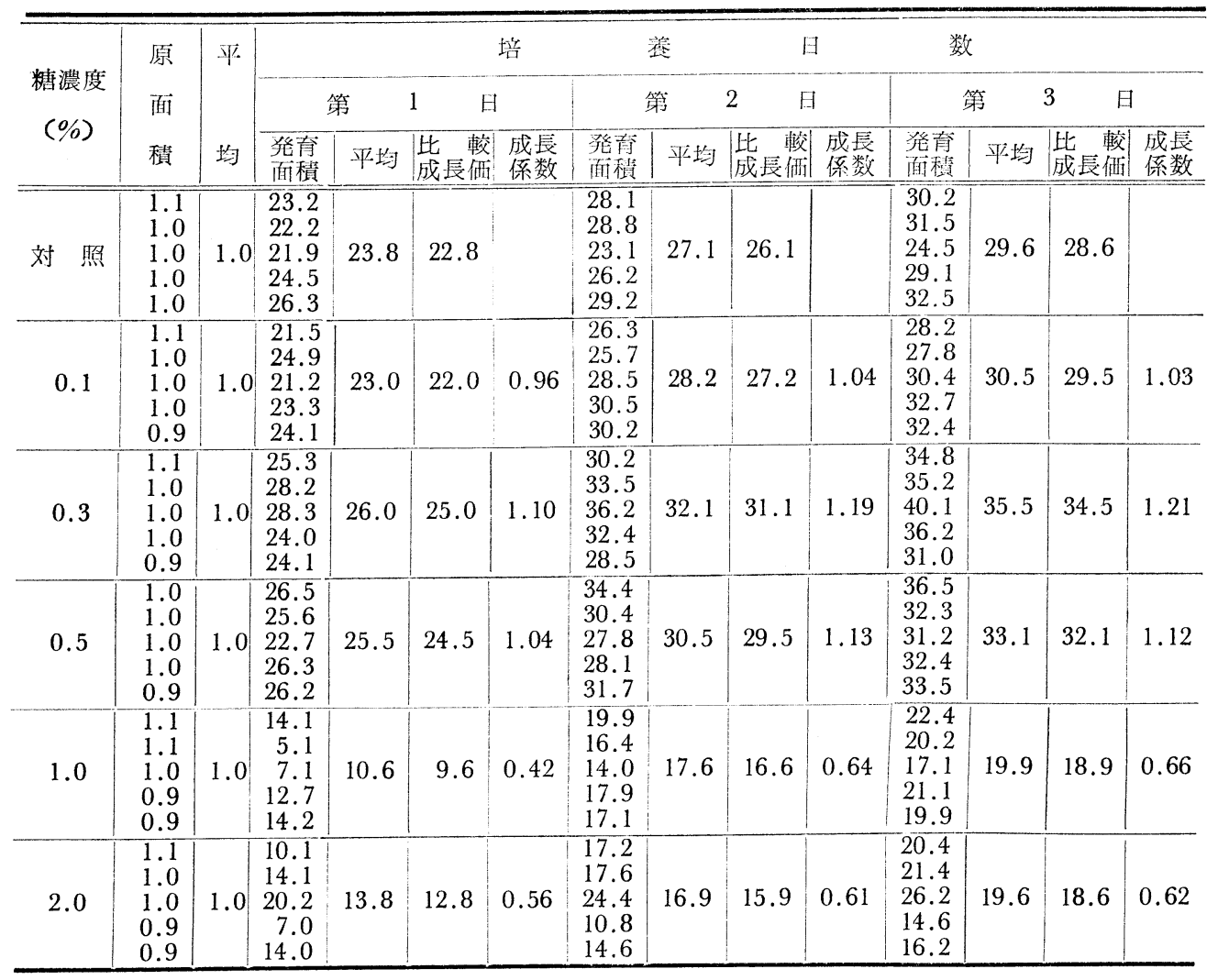


第60表 平均值 (脾臟)

\begin{tabular}{|c|c|c|c|}
\hline \multirow{2}{*}{$\begin{array}{c}\text { 糖浱度 } \\
(\%)\end{array}$} & 培 & 㖉 & 数 \\
\hline & 第 1 日 & 第 2 日 & 第 3 日 \\
\hline 0.1 & 1.04 & 1.04 & 1.03 \\
\hline 0.3 & 1.21 & 1.16 & 1.20 \\
\hline 0.5 & 1.20 & 1.14 & 1.10 \\
\hline 1.0 & 0.58 & 0.71 & 0.71 \\
\hline 2.0 & 0.53 & 0.59 & 0.61 \\
\hline
\end{tabular}

\section{第 4 章 総括並びに考按}

現今糖尿病患者に初影る抵抗減弱の原因として一般に信ぜられて いるものは，1）渦血糖觉重視するもの，2）インシュリン人乏に因 るとするもの，3）アセトン体の有毒性に带せんとするものであり， 乙れ等に関する業績は多いがその原团関しては明確でない点が少 くなく諸家により種々異論の存する所である。

即ち臓器組織の抵抗減弱を過血糖そのものに因るとするものは Naunyn ${ }^{21)}$ 以来穴の数は多く, Wieland ${ }^{22}$ は過血糖が糖尿病に於ける 合併症に対し原因的関係のあるとと总垫め，Falta ${ }^{23)}$ は糖尿病に見ら

れる多くの二次的症状は過血糖によるもので，長期汇亘る過血糖は新陳代謝の障碍党增加せしめるものであ

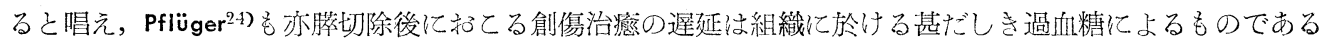

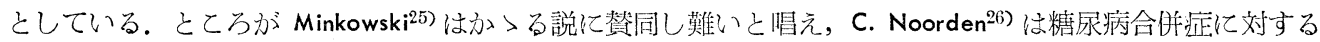
原因は多種多様で過血糖のみが抵抗減弱の原因でないとしている。我が教室の研究成果からみても, 過血糖

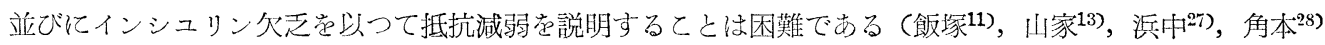
等).

抵抗性減弱がアチドージスに起因するとなすものる少くないが，C. Noorden 法糖尿病に於ける特殊な中毒 の総てを $\beta$-oxybuttersäure の特異性によるものとは認好難いとし，教室の浜中 ${ }^{27}$ ，山家 ${ }^{14)}$ 等も組織呵吸， 組織培養の面汃らその毒性を検討し，糖尿病昏睡時の血中アセトン量より遥かに高濃度の 0.05〜0.1\%のア セトン溶液でも組織呼吸並びに組織生育はむしろ良好であると報告している等，アチドージスを以つて組織 抵抗減弱の原因とするのも理解し難い。

蓋し清野-Aschoff ${ }^{29)}$ が細網内皮系は体内新陳代謝に或は免疫現象に 或は解毒作用に密接な関係があり，新 陳代謝並びに生体防集現象に重大な意義を有するものであると元い，一般に該内皮細胞系の機能の変調は物 質代謝異常尼来し引いては生体防禦機転の障碍を招来するものであると云われている.

糖尿病に於ける抵抗減弱の一因は乙の細網内皮系機能の障碍に原因するものではないかとも想像され，糖 尿病の該系統の機能に関する研究も少くない。つとに舘石教授 ${ }^{16)}$ は糖尿病患者に於て，柴田 ${ }^{30}$ は「ア糖尿家 鬼を用いてコンゴロート系数を測定し，機能の減退を報告している等一般に該系統の機能の低下を恩めてい る学者が多い.

又橋本 ${ }^{31}$ は赤血球病態生理总基調として種々検索した結果，糖尿病㭧者の諸種臟器組織の抵抗減弱は主々

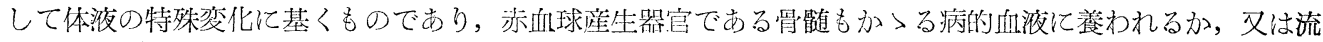
血中に出でたる血球が病的体液中に浮游する為赤血球直径は增大するとし, 塙本 ${ }^{32}$ は糖尿病患者の血糖量々 骨鹃迶糖舅との間に著差はないとしている.

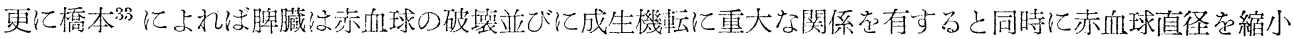

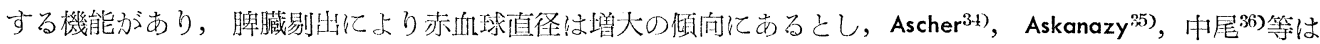

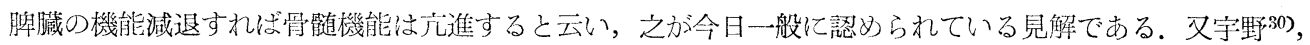

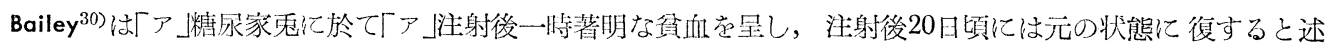
ベている.

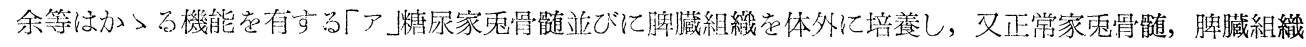

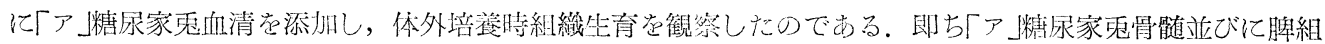

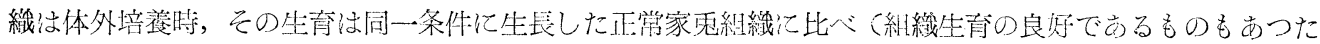

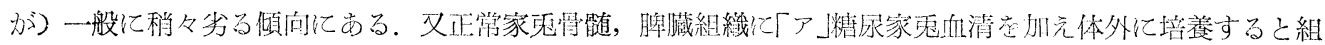

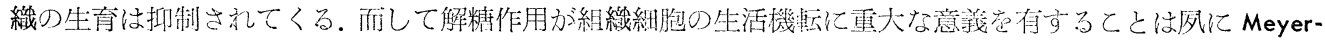

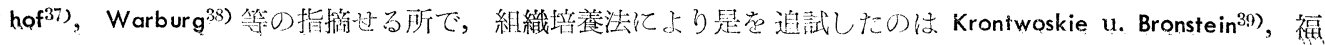




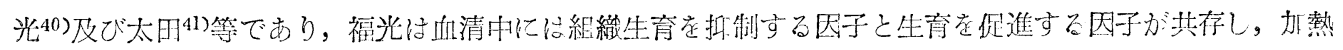
に上り組織生育促進物質统破壊せられ組織の生育は抑制されると述べている.

我が教室では飯塚名答教授から引継ざ過去20数年来糖尿病の抵抗減弱行関する研究が続けられて来たが, 角本 ${ }^{28)}$, 浜中 ${ }^{27}$ は組織呼吸より，舘石教授 ${ }^{22}$ ，山家 ${ }^{13,14)}$ は組織培養により糖尿病者血清中に有毒物質の存在 することを証明し，該有毒物質は熱に対し抵抗弱く，又アセトン体でもないととを立証し，更に橋本・太田 ・田中42)等は糖尿病者血清の有毒物質について検索し非滤過性且被吸着性なることを見出したのである.

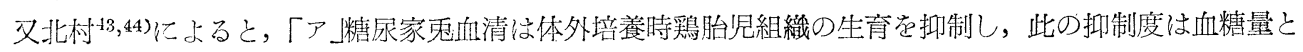

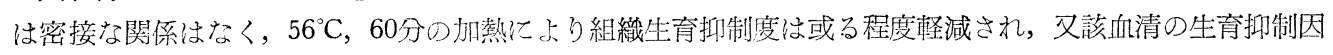
子の一部はシャンベラン $\mathrm{L}_{3}$ 滤過器を通過せず，且つカオリン，血炭末により吸着されるととを報告したの

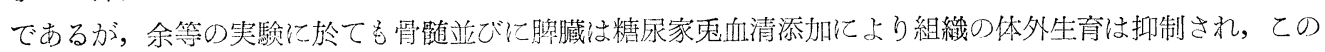

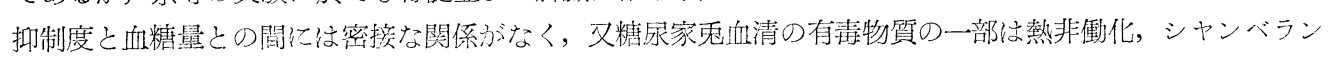
L s 滤過器の滤過, カオリン, 血炭末の吸着等によりその生育抑制度は或る程度軽減されるととを知つた。 而し，尚非処監正常血清よりも組織生育抑制度は著明である。

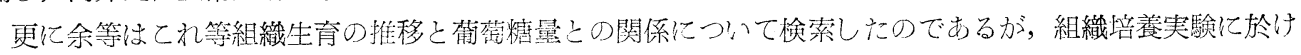

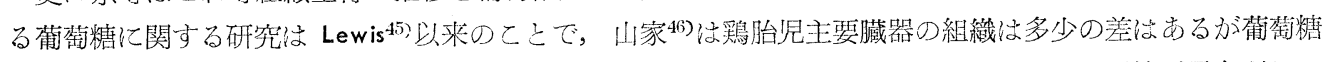
濃度の0.3 0.5\%でその生育は最う旺盛であり, 又諸藏器組織中肺組織は葡蕧糖に対する抵抗が最も弱かつ たと報告している。蓋し糖と組織抵抗減弱々の関係はNaunyn'1)以来のととで，Kayser(7)初め多くの学者が渦

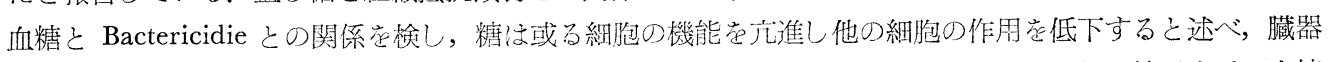

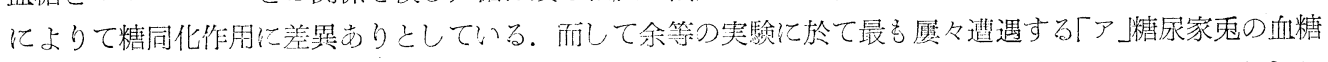

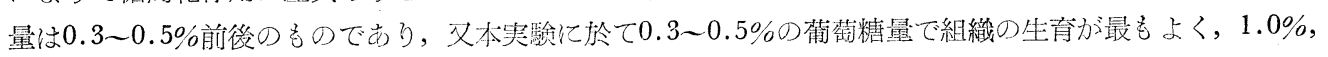

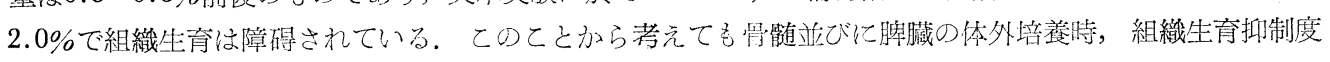
と葡葡糖量との間には值接関係がないるのと思われる。

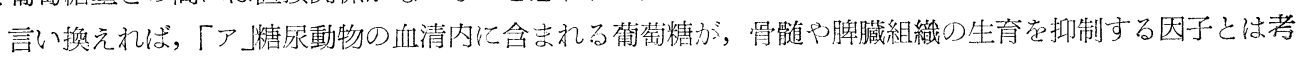
えられない，他汭原因を求すべきである。

\section{第 5 章 結}

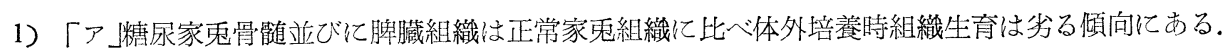

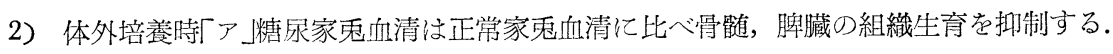

3) 組織生育抑制著明な「ア糖永家鬼血清化熱非働化, シャンベラン $\mathrm{L}$ 濾過器の滤過, 吸着䯇（カオリ ン，血炭末）上る吸着等の処置をすると組織生育抑制度が減弱される。

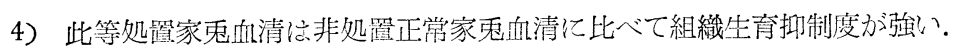

5）正常家鬼血清に此等の処置をしても組織の生育度隹非処羁正常血清と殆んど変らない.

6) 組織生育抑制之葡䓱糖量との間亿密接な関係㹥認められない.

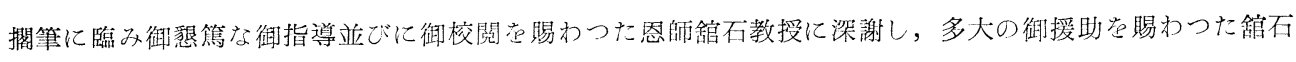
内科教室北村博士に满腔の意を表方る。

尚本研究は文部省科学研究費住う所大である。

\section{文献}

1) Kestermann E. u. A. Knolle: Dtsch. Arch. Klin. Med. 176, 64 (1939). $\quad$ 2) Buiwid: Centralbl. f. Bakteriol. 4, 577 (1888). 3) Grossman: Über gangrän by Diabetes mellitus Berlin (1900). 4) Hildenbrandt : Dtsch. Zeitschr. f. chirurg. 72, 3.51 (1904). 5 5) Hayasi: Grafes Arch. f. ophtal. 76, 159 (1910). 6) Handmann: Dtschr. Arch. Klin. Med. 102,1 (1911). 7) 竹村: 日微学会誌,

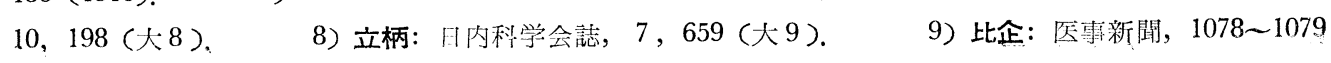


(大10). 10) 鈴木：日内分泌学会誌，5，523(炤 4). 11 ) 飯塚：臨烌日本，1，813(朋 9 ).

12) 舘石: 日消化会誌, 15,242 (昭 8 ).

13) 山家: 京府医大誌，20，2，824 (炤12).

山家：同誌，20, 3, 1242 (昭12).

15) Kestermann, E. u. K.E. Vogt: Dtsch. Klin. Med. 185, 258

(1939). 16) 舘石：京府医大誌， 4, 1, 27 (昭 5 ).

18) Jacobs: The treatment of diabetes mellitus. 178.

(昭30). 20) 木村: 組織培養の研究 (昭 5).

Wieland: Zbl. physiol. u. path. 5, 481 (1910).

Pflüger: Pflugers Arch. 106, 181 (1905).

C. Noorden: Die Zuckerkrankheiten. 6, Aufl. (1912).

29) 清野-Aschoff : Fol. haemat. 15, 383 (1913).

31) 橋本: 京府医大誌，9，2，323 (昭 8 ).

33) 橋本, 山本: 京府医大誌, 21, 2,729 (昭12).

17) Aschoff : Erg. inn. Med. 26, 1 (1924)

19) 舘石, 增田: 日内科学会誌, 44, 5, 73

21) Naunyn: Zit nach G. Noorden (26). 22)

23) Falta: Arch. int. Med. 5. 28 (1908). 24)

25) Minkowski : Berl. Kl. Wschr. 42 (1893). 26)

28) 角本: 同誌, 8, 299 (昭 8 ).

本: 糖尿病の実験病理学 (昭26).

(1917).

35) Askanazy: Schweiz. med. Wschr. 681 (1932).

Ascher u. Dubois : Biochem. Z. 82, 141 (1917)

37) Meyerhof: Pflugers Arch. 185, 25 (1920).

38)

Warburg: Über den Stoffwechsel der Tumoren. ott. Warburg. (1920).

39) Krontwoskie u. Bronstein :

Arch. exper. Zellforschg. 3, 32 (1926).

40) 福光：日微学会誌，24, 1279 (昭 5 ).

41) 太田:

同誌, 24,213 (昭 5 ).

42) 橋本, 太田, 田中:

43) 北村:

同誌, 29,73 (炤28).

44) 北村: 回誌, 30, 3, 144 (昭29).

35, 317 (1922).

46) 山家: 京府医大誌，20,3，1242 (昭12).

(1902). 